\title{
THE DESIGN OF A COMPREHENSIVE MICROSIMULATOR OF HOUSEHOLD VEHICLE FLEET COMPOSITION, UTILIZATION, AND EVOLUTION
}

\author{
Rajesh Paleti \\ The University of Texas at Austin \\ Dept of Civil, Architectural \& Environmental Engineering \\ 1 University Station C1761, Austin TX 78712-0278 \\ Phone: 512-471-4535, Fax: 512-475-8744, Email: rajeshp@mail.utexas.edu
}

\author{
Naveen Eluru \\ McGill University
}

Department of Civil Engineering and Applied Mechanics

817 Sherbrooke Street West, Montreal, Quebec, Canada H3A 2K6

Phone: 514-398-6856, Fax: 514-398-7379, Email: naveen.eluru@mcgill.ca

Chandra R. Bhat* (corresponding author)

The University of Texas at Austin

Dept of Civil, Architectural \& Environmental Engineering

1 University Station C1761, Austin TX 78712-0278

Phone: 512-471-4535, Fax: 512-475-8744, Email: bhat@mail.utexas.edu

\section{Ram M. Pendyala \\ Arizona State University}

School of Sustainable Engineering and the Built Environment

Room ECG252, Tempe, AZ 85287-5306

Phone: 480-727-9164, Fax: 480-965-0557, Email: ram.pendyala@asu.edu

Thomas J. Adler

Resource Systems Group, Inc.

55 Railroad Row, White River Junction, VT 05001

Phone: 802-295-4999, Email: tadler@rsginc.com

\author{
Konstadinos G. Goulias \\ University of California \\ Department of Geography \\ Santa Barbara, CA 93106-4060
}

Phone: 805-308-2837, Fax: 805-893-2578, Email: goulias@geog.ucsb.edu 
Paleti, Eluru, Bhat, Pendyala, Adler, and Goulias

\begin{abstract}
This paper describes a comprehensive vehicle fleet composition, utilization, and evolution simulator that can be used to forecast household vehicle ownership and mileage by type of vehicle over time. The components of the simulator are developed in this research effort using detailed revealed and stated preference data on household vehicle fleet composition, utilization, and planned transactions collected for a large sample of households in California. Results of the model development effort show that the simulator holds promise as a tool for simulating vehicular choice processes in the context of activity-based travel microsimulation model systems.
\end{abstract}




\section{INTRODUCTION}

Activity-based travel demand model systems are increasingly being considered for implementation in metropolitan areas around the world for their ability to microsimulate activitytravel choices and patterns at the level of the individual decision-maker such as a household or individual. Due to the microsimulation framework adopted in these models, they are able to provide detailed information about individual trips, which in turn can result in substantially improved forecasts of greenhouse gas (GHG) emissions and energy consumption (1). In this context, one of the critical choice dimensions that has a direct impact on energy consumption and GHG emissions is that of household vehicle fleet composition and utilization (2). In light of global energy consumption and emissions concerns, several studies in the recent past have focused attention on the types of vehicles owned by households - the type of vehicle being defined by some combination of body type or size, fuel type, and the age of the vehicle - as well as the mileage (utilization) of the vehicles (for example, see $(3,4)$ ). These studies explicitly recognize that energy consumption and GHG emissions are not only dependent on the number of vehicles owned by households, but also on the mix of vehicle types and the extent to which different vehicle types are utilized (driven).

The literature has recognized for a long time, however, that household vehicle ownership (or fleet composition and utilization) models are only capable of providing a snapshot of vehicle holdings and mileage, as such models are routinely estimated on cross-sectional data sets that offer little to no information on vehicle transactions over time $(5,6)$. As the focus of transportation planning is largely on forecasting demand over time, it is desirable to have a vehicle fleet evolution model that is capable of evolving a household's vehicle fleet over time (say, on an annual basis) by analyzing the dynamics of vehicle transaction decisions over time. In addition, the vehicle evolution model system should be sensitive to a range of socio-economic and policy variables to reflect that vehicle transaction decisions are likely influenced by the types of vehicle technologies that are and might be available, public policies and incentives associated with acquiring fuel-efficient or low/zero-emission vehicles, and household socio-economic and location characteristics (7-9).

Unfortunately, however, the development of dynamic transactions models has been hampered by the paucity of longitudinal data on vehicle transactions that inevitably occur over time. Mohammadian and Miller (10) use about 10 years of data to model vehicle ownership by type and transaction decisions over time, but do not include fuel type as one of the attributes of vehicles. Yamamoto et al. (11) use panel survey data to model vehicle transactions using hazardbased duration formulations as a function of changes in household and personal demographic attributes. Their study also shows the role of history dependency in vehicle transaction decisions with a preceding decision in time affecting a subsequent transaction decision. Two other studies in the recent past- Prillwitz et al. (12) and Yamamoto (13) focused on the impact of life course events on car ownership patterns of households using panel data. Prillwitz et al (12) estimated a binary probit model to analyze the increase in car ownership level (1 corresponding to an increase and 0 otherwise) using German Socioeconomic panel data from 1998 to 2003, while Yamamoto (13) developed hazard-based duration models and multinomial logit models to analyze the vehicle transaction decisions using panel data in France and retrospective survey data for Japan respectively. It is impossible to present a comprehensive literature review on this topic within the scope of this paper (see de Jong et al. (14) and Bhat et al. (3) for reviews), but suffice it to say that studies of dynamic vehicle transactions behavior emphasize the need for simulating vehicle fleet composition and utilization over time to accurately estimate energy consumption 
and GHG emissions arising from human activity-travel choices. However, because of the difficulty of collecting data over time (including costly design/implementation of panel surveys and survey attrition over time; see Bunch (15)), dynamic models have focused primarily on vehicle ownership (i.e., transactions) with inadequate emphasis on the vehicle type, usage, and vintage considerations of the household fleet. Further, in today's rapidly changing vehicle market, a substantial limitation of panel models based solely on revealed choice data is that these models do not consider the range of vehicle, infrastructure, and alternative fuel advances on the horizon, and thus are insensitive to technological evolution.

This paper offers a comprehensive vehicle fleet composition, utilization, and evolution framework that can be easily integrated in activity-based microsimulation models of travel demand. The model includes several components that allow one to not only predict current (baseline) vehicle holdings and utilization (by body type, fuel type, and vintage) but also simulate vehicle transactions (including addition, replacement, or disposal) over time. The usual data limitation is overcome in this study through the use of a unique large sample survey data set collected recently in California. Specifically, the survey not only included a revealed choice component of current vehicle holdings and vehicle purchase history, but also a stated intentions component related to intended vehicle transactions in the future and a stated preference component eliciting information on vehicle type choice preferences. By pooling data from these components, we are able to include a range of vehicle types (including those not commonly found in the market place) in a vehicle type choice model, and test the effects of a range of policy variables on vehicle fleet composition, utilization, and evolution decisions.

The next section describes the proposed vehicle simulator framework. The third section provides an overview of the data set and survey sample. The fourth section presents the methodology. The fifth section discusses model estimation results, while the sixth section provides model evaluation statistics. The final section offers concluding thoughts.

\section{VEHICLE FLEET COMPOSITION AND EVOLUTION FRAMEWORK}

Figure 1 presents the vehicle fleet composition and evolution framework used in the current study. First, there is a base year (baseline) model capable of predicting the current vehicle fleet composition and utilization of a household. In order to recognize the fact that the vehicles owned by a household at any given point in time are not acquired contemporaneously, the household is deemed to have acquired the vehicles on multiple choice occasions. Based on extensive analysis of travel survey data sets, it has been found that the number of vehicles owned by a household is virtually never greater than the number of adults in the household plus two (in the data set used in the current analysis, $99.7 \%$ of households were covered by the condition that the number of vehicles is no greater than the number of adults plus two; note also that our approach is perfectly generalizable to the case where the number of vehicles is never greater than the number of adults plus $K$, where $K$ is any positive integer determined by the analyst based on the data being studied). Then, each household is assumed to have a number of "synthetic" choice occasions (on which to acquire a vehicle) equal to the number of household adults plus two. In the figure, an example is shown for a two-adult household with four possible choice occasions. In each choice occasion, a household may acquire a vehicle and associate an amount of mileage (utilization) to it, or may not acquire a vehicle at all. Further, since the temporal sequence of the purchase of the vehicles owned by the household is known, we are able to accommodate the impacts of the types of vehicles already owned on the type of vehicle that may be purchased in a subsequent purchase decision. This "mimics" the dynamics of fleet ownership decisions. 
Once the base year fleet composition and utilization has been established for each household, the simulator turns to the evolution component. The evolution component works on an annual basis with households essentially faced with a number of possible choice alternatives (decisions). For each vehicle in the household, a household may choose to either dispose the vehicle (without replacing it) or replace the vehicle (involving both a disposal and an acquisition). If the choice is to replace the vehicle, then the vehicle selection module model estimation results can be applied to determine the type of vehicle that is acquired and the mileage that is allocated to it. Finally, a household may also choose to add a net new vehicle to the household fleet. In the case of an addition, once again the vehicle type choice and utilization model from the first simulator component can be applied to the vehicle acquired. Note that this framework overcomes the limitations of past studies that generally allowed only one possible transaction in any given year. Further, dependency between transaction decisions can be accommodated by including the number of years since an earlier transaction decision. For example, a vehicle may be less likely to be replaced if another vehicle was replaced the year before or if a vehicle was added the year before. Similarly, a vehicle may be less likely to be added if a vehicle was added the year before or if another vehicle was replaced the year before.

\section{DATA}

The data for the current study is derived from the residential survey component of the California Vehicle Survey data collected in 2008-2009 by the California Energy Commission (CEC) to forecast vehicle fleet composition and fuel consumption in California. The survey included three components, which are briefly discussed in turn in the next three paragraphs.

The revealed choice (RC) component of the survey collected detailed information on the current household vehicle fleet and usage. This included information about the vehicle body type, make/model, vintage, and fuel type for each vehicle. In addition, the annual mileage that each vehicle is driven/utilized and the identity of the primary driver of each vehicle are also collected. The survey then included a set of questions to probe whether a household intended to replace an existing vehicle or acquire a net new additional vehicle in the fleet, and the characteristics of the vehicle(s) intended to be replaced or purchased (SI or stated intentions data). Essentially, the stated intention (SI) component of the survey gathered detailed information on replacement plans for each vehicle in the household fleet (over the next 25 years), and plans for adding net new vehicles (within the next five year period).

Finally, households that intended to purchase a vehicle either as a replacement or addition, and for whom there was adequate information on current revealed choices, were recruited for participation in a stated preference exercise (SP data). The SP exercises included several vehicle types and fuel technology options not currently available in the market, thus providing a rich data set for modeling vehicle transaction choices in a future context. The exercises involved the presentation of eight choice scenarios with four alternatives in each scenario. Attributes considered in describing each alternative included the vehicle type, size, fuel type, and vintage; a series of vehicle operating and acquisition cost variables; fuel availability, refueling time, and driving range; tax, toll, and parking incentives or credits; and vehicle performance (time to accelerate $0-60 \mathrm{mph}$ ).

The revealed choice (RC) and stated intentions (SI) data on current vehicle fleet composition and utilization was collected for a sample of 6577 households. Among these households, the stated preference (SP) component was administered to a sample of 3274 households who indicated that they would undertake at least one transaction in the future. The 
development of models for the vehicle simulator involved pooling the revealed choice (RC), stated intentions (SI) and stated preference (SP) components of the data, while pinning vehicle choice and usage behavior to current revealed choices.

The vehicle selection module estimation was undertaken using a random sample of 1165 respondent households with complete information. Care was taken to ensure that the distributions of vehicle types, fuel type and vintage in the estimation data set were the same as those in the original data set of 6577 observations. The discrete dependent variable in the vehicle selection module estimation is a combination of six vehicle body types (compact car, car, small cross utility vehicle, sport utility vehicle or SUV, van, and pick-up truck), seven fuel types (gasoline, flex fuel, plug-in hybrid, compressed natural gas (or CNG), diesel, hybrid electric, and fully electric), and five age categories (new, 1-2 years, 3-7 years, 8-12 years, and more than 12 years old). In addition, the no-vehicle choice category exists as well. Thus, there are a total of 211 alternatives in this choice process. The continuous dependent variable in the vehicle selection module estimation is the logarithm of the mileage traveled using each vehicle. The vehicle evolution component of the model system developed in this paper includes the choice of replacement or addition of a vehicle. No information was collected on vehicle disposal plans and hence this choice dimension could not be considered using this data set. Of the 1165 household sample used for estimating the vehicle selection module, 915 households had complete information on vehicle transaction details (SI data). The replacement choice process is represented as an annual decision for each household, with replacement decisions beyond five years grouped into a single category of "five or more years". Although the population is aged in the model estimation data set, many demographic changes are not taken into account (such as changes in number of workers, household income, household size, etc.) in the current effort; in ongoing work, the vehicle simulator described here is being integrated with a demographic evolution simulator to fully evolve households and their vehicle fleets over time.

\section{METHODOLOGY}

\subsection{Vehicle Selection Module}

The vehicle selection module employs the traditional discrete-continuous framework for modeling the base year vehicle fleet composition and utilization. The vehicle fleet is described by a multinomial logit model of vehicle body type, fuel type, and vintage, and mileage (in logarithmic form) is modeled using a linear regression model. The methodology is the same as that described in Eluru et al. (16). As discussed earlier in Section 2, the vehicle fleet and usage decisions are assumed to occur through a series of unobserved (to the analyst) vehicle choice occasions, with the number of vehicle choice occasions being equal to $N+2$ ( $N$ being the number of adults in the household).

Let $q$ be the index for the households, $q=1,2,3, \ldots, Q$ and let $i$ be the index for the vehicle type alternatives. Let $j$ be the index for the vehicle choice occasion $j=1,2, \ldots ., J_{q}$ where $J_{q}$ is the total number of choice occasions for a household $q$ which is equal to $N+2$ (from RC data), plus the number of choice occasions where a replacement/addition decision was observed/reported (from SI data), plus up to eight choice occasions from the stated preference questionnaire (from SP data). With this notation, the vehicle type choice discrete component takes the following form:

$$
u_{q i j}^{*}=\beta^{\prime} x_{q i j}+\varepsilon_{q i j}
$$


$u_{q i j}^{*}$ is the latent utility that the $q$ th household obtains from choosing alternative $i$ at the $j$ th choice occasion. $x_{q i j}$ is a column vector of known household attributes at choice occasion $j$ (including household demographics and vehicle fleet characteristics before the $j$ th choice occasion), $\beta$ is the corresponding coefficient column vector of parameters to be estimated, and $\varepsilon_{q i j}$ is an idiosyncratic error term assumed to be independently and identically type-I extreme value distributed across alternatives, individuals, and choice occasions. Its scale parameter is normalized to one for revealed preference (RP) choice occasions and specified as $\frac{1}{\lambda}$ for the stated intention (SI) and stated preference (SP) choice occasions.

Then, the household $q$ chooses alternative $i$ at the $j$ th choice occasion if the following condition holds:

$$
u_{q i j}^{*}>\max _{s=1,2, \ldots, I, s \neq i} u_{q s j}^{*}
$$

The above condition can be written in the form of a series of binary choice formulations for each alternative $i$ (17). Let $R_{q i j}$ be a dichotomous variable that takes the values 0 and 1 , with $R_{q i j}=1$ if the $i$ th alternative is chosen by the $q$ th household at the $j$ th choice occasion, and $R_{q i j}=0$ otherwise. Then, Equation (2) can be written as follows:

$$
R_{q i j}=1 \text { if } \beta^{\prime} x_{q i j}>v_{q i j},(i=1,2, \ldots, I)
$$

where $v_{q i j}=\left\{\max _{s=1,2, \ldots, I, s \neq i} u_{q s j}^{*}\right\}-\varepsilon_{q i j}$ follows:

The vehicle mileage component takes the form of a classical log-linear regression as

$$
m_{q i j}^{*}=\alpha^{\prime} z_{q i j}+\eta_{q i j}, \quad m_{q i j}=1 \quad\left[R_{q i j}=1\right] m_{q i j}^{*}
$$

In the above equation, $m_{q i j}^{*}$ is a latent variable representing the logarithm of annual mileage for the vehicle type $i$ if it had been chosen at the $j$ th choice occasion. $z_{q i j}$ is the column vector of household attributes, $\alpha^{\prime}$ is the corresponding column vector of parameter to be estimated, and $\eta_{q i j}$ is a normal error term assumed to be independent and identically distributed across households $q$ and choice occasions $j$, and identically distributed across alternatives $i$ $\left(\eta_{q i j} \sim N\left[0, \sigma_{\eta}^{2}\right]\right)$. Also, since the annual mileage is observed only for the chosen vehicle type at each choice occasion, any dependence between the $m_{q i j}^{*}$ terms across alternatives is not identified,

The two model components discussed above are brought together in the following equation system:

$$
\begin{aligned}
& R_{q i j}=1 \text { if } \beta^{\prime} x_{q i j}>v_{q i j},(i=1,2, \ldots, I)(j=1,2, \ldots, J) \\
& m_{q i j}^{*}=\alpha^{\prime} z_{q i j}+\eta_{q i j}, \quad m_{q i j}=1 \quad\left[R_{q i j}=1\right] m_{q i j}^{*}
\end{aligned}
$$


Copula based methods are used to determine the dependencies between the two stochastic terms $v_{q i j}$ and $\eta_{q i j}$ to account for common unobserved factors influencing vehicle type and usage decisions. In the copula method, the stochastic error terms are transformed into uniform distributions using their inverse cumulative distribution functions which are subsequently coupled into multivariate joint distributions using copulas (10). The expression for the loglikelihood is similar to the one in Eluru et al. (10). Six different copulas were used in this paper: (1) Gaussian copula, (2) Farlie-Gumbel-Morgenstern (FGM) copula, (3) Clayton, (4) Gumbel, (5) Frank, and (6) Joe copulas (18).

\subsection{Vehicle Evolution Module}

The vehicle selection module results are used even in the vehicle evolution module for predicting vehicle type and usage. In addition, a binary logit model form is used for modeling both the vehicle replacement and addition decisions (on an annual basis). Let $q$ be the index for the households, $q=1,2,3, \ldots, Q$, let $i$ be the index for the vehicle in the household and let $j$ be the index for the vehicle replacement/addition occasion $j=1,2, \ldots, J_{q}$ where $J_{q}$ is the total number of choice occasions for a household $q$ which is equal to $\min \left\{t_{q i}, 5\right\}$, where $t_{q i}$ is the number of years in which the household is planning to replace/add a vehicle $i$. For example, if a household with two vehicles plans to replace its first vehicle in two years, replace its second vehicle in five years, and add a vehicle in three years, then two choice occasions were created for the replacement decision of the first vehicle $(0,1)$, five choice occasions for the replacement decision of the second vehicle $(0,0,0,0,1)$, and three choice occasions for the addition decision $(0,0,1)$, where 1 corresponds to an addition/replacement decision and 0 corresponds to a do-nothing option. With this notation, the vehicle evolution models take the following form:

$$
l_{q i j}^{*}=\gamma^{\prime} w_{q i j}+\vartheta_{q i j}, \quad l_{q i j}=1 \text { if } l_{q i j}^{*}>0 ; l_{q i j}=0 \text { otherwise }
$$

$l_{q i j}^{*}$ is the latent utility that the $q$ th household obtains from choosing to replace/add vehicle $i$ at the $j$ th choice occasion. $w_{q i j}$ is a column vector of known household attributes at choice occasion $j$ (including household demographics and vehicle fleet characteristics before the $j$ th choice occasion), $\gamma$ is the corresponding column vector of parameters to be estimated, and $\vartheta_{q i j}$ is an idiosyncratic error term assumed to be independently and identically type-I extreme value distributed across alternatives, individuals, and choice occasions.

\section{MODEL ESTIMATION RESULTS}

A sample of 1165 households with complete information provided the basis for estimating the model components. Descriptive statistics for this sample of households (as obtained from RC data) are shown in Table 1. Car, van, and SUV are the predominant vehicle types; annual mileage driven tends to be larger for larger vehicles than for cars, presumably because households use larger vehicles for longer trips. Less than two percent of the households report having no vehicle. All of the other descriptive statistics show a reasonable distribution of attributes that makes the sample suitable for estimating choice models.

\subsection{Vehicle Selection Module}

The vehicle selection module includes the vehicle type choice model component (results are in Table 2a) and the vehicle mileage component (results are in Table 2b). For the vehicle type 
component, we considered the overall utility of a vehicle type as the sum of independent utility components for the body type, fuel type, and vintage of the vehicles. While we also considered interaction effects, such effects were generally not statistically significant. Thus, Table 2a presents the effects of variables in three row panels: the first row panel corresponds to body types (including the "no vehicle" option), the second to fuel types, and the third to vehicle vintage. The results offer behaviorally intuitive interpretations. Strictly speaking, the constants (first column of Table 2a) cannot be directly compared across the body types because of the presence of several continuous variables in the model specification, but the magnitudes of the constants on the different body types suggest a greater preference to own a compact car or a car compared to other vehicle types. In the second row panel, similarly, gasoline fuel vehicles are the most preferred, while compressed natural gas (CNG) and fully electric vehicles are the least preferred. The final row panel suggests, as expected, that households have a strong preference for newer cars.

A range of policy sensitive variables were included in the model, as shown in Table 2a. These are all estimated as generic effects (that is, a single effect is estimated for each variable across all alternatives as indicated by the dotted lines separating the three panels in Figure 1). All of the cost-related variables (purchase price, fuel cost per gallon, fuel cost per year $\$ 10000$, and maintenance cost per year $/ \$ 1000$ ) have negative coefficients indicating that as cost increases, the preference for a vehicle type decreases. Two vehicle performance variables were considered. The time to accelerate from 0 to $60 \mathrm{mph}$ has a negative impact on the utility of an alternative, indicating that, in general, vehicles with more powerful engines are preferred. Similarly, fuel efficiency (measured in miles per gallon) also has a positive impact on utility. Interestingly, we find that policy variables that offered incentives such as car pooling, free parking, \$1000 tax credit, 50 percent reduction in tolls, and \$1000 off the purchase price all have similar magnitudes of effects on enhancing the utility of various alternatives. In other words, one policy incentive did not clearly outshine the others in terms of influencing vehicle type choice. But, all these policy variables are statistically significant in the final model.

In the category of fuel infrastructure and vehicle range, for CNG and electric vehicles, the greater availability of refueling stations positively affects vehicle type choice (note the negative sign on the "fuel available - 1 in 50 stations" variable in Table 2a; the base for introducing this variable was "fuel available - 1 in 20 stations"). Refueling time, however, did not turn out to be statistically significant. Also, for CNG and electric vehicles, those with medium (150-200 miles) and high (>200 miles) driving ranges are preferred over those with lower ranges.

As expected, a range of household socio-economic and demographic variables significantly affects vehicle type choice. Households with more male adults have a stronger preference (relative to households with fewer males) for larger vehicles as opposed to compact cars and small cross utility vehicles, and were more likely to own older ( $>12$ years) vehicles (an adult is defined as an individual over 15 years of age). Interestingly, these households have a lower preference for plug-in hybrid and hybrid electric vehicles than households with fewer males. On the other hand, households with more female adults have a higher propensity (than households with few female adults) to own sports utility vehicles (SUVs) and move toward owning fully electric vehicles, while also shying away from diesel-powered vehicles.

As the household income increases, the inclination to get older vehicles decreases. These households are likely to be able to afford newer vehicles and have a preference to do so. Also, higher income households show a preference for a mix of vehicle body types including both small and large vehicles, suggesting that these households are able to afford a mix of vehicle 
body types for different types of trips. Households located in suburban regions are more inclined to own regular gasoline or diesel or CNG fueled sports utility and/or pick-up vehicles, while households in rural areas are more likely to own pick-up vehicles and diesel/hybrid fueled vehicles (the base category was households residing in urban regions). Those with a higher education level tend to have a preference for newer vehicles and alternative fuel vehicles. It is possible that these individuals are more environmentally sensitive, leading to their preference for less polluting vehicles (the education level of high school or below was the base category for introducing education effects). Households with younger children prefer larger vehicles, consistent with the notion that families probably like the room offered by such vehicles. Households with older children have a preference for acquiring older vehicles, perhaps because parents get teenagers older vehicles when they first begin driving. On the other hand, households with senior adults (>65 years of age) prefer newer vehicles, possibly because these households want trustworthy cars that are perceived to be safe.

A set of findings hard to explain is that Caucasian households are more likely to prefer cars over larger vehicles, older vehicles over newer vehicles, and traditional fuel vehicles over alternative fuel vehicles. It is not immediately clear why these preferences exist for this group in comparison to other groups. Similarly, it is not readily apparent why households with more fulltime and part-time workers with a work location outside home should prefer older cars relative to new cars, while households with several full-time workers working from home would have a propensity to own new cars. Finally, households with several employed individuals working from home are more likely to own SUVs and vans.

The existing household vehicle fleet has a significant impact on vehicle type choice/selection. Among the many effects of existing household fleet, the one that particularly stands out is that households prefer less any vehicle body type that already exists in their fleet. With respect to replacement (last page of Table 2a), there are several tendencies, but an overarching result is that households are more prone to replace a vehicle in the fleet with the same body type of vehicle. If the replaced vehicle is a compact car, it is likely to be replaced with a non-gasoline fueled vehicle but also not the newest of vehicles (possibly because current compact car owners are more environmentally conscious but also cost-conscious, which leads them to seek "green" vehicles but not the newest vehicles). A car is unlikely to be replaced with a pick-up. Also, in general, any non-compact car is unlikely to be replaced with a compact car. When the replaced vehicle is a SUV, households tend to replace it with a diesel-powered engine, and with a newer vehicle rather than an older one. Households which replace a gasoline fuel vehicle are more likely to replace it with an alternative fuel vehicle rather than a diesel fuel vehicle. This suggests that households looking to replace an existing gasoline vehicle are likely to consider newer alternative fuel vehicles; public policies aimed at offering incentives may provide the needed impetus to move in the direction of a greener fleet.

The vehicle usage (mileage) model component in Table $2 \mathrm{~b}$ also yield largely intuitive results as well. Households with higher incomes are associated with higher travel mileage, consistent with the notion of more financial freedom to engage in out-of-home discretionary pursuits. Households with small children tend to have larger mileage, perhaps because these households have errands to run and serve-child trips that accumulate miles. Households in suburban regions also travel more than other households, possibly because suburban locations are more auto-oriented. Households with senior adults greater than 65 years of age tend to have lower mileage, presumably because these households consist of retired individuals living in empty nests. Households with more vehicles have lower mileage on a per vehicle basis, a 
manifestation of the ability to divide total household travel among multiple vehicles. Households with more workers have larger mileage, presumably due to greater levels of work travel. Similarly, households in which individuals are farther from their work places accumulate more mileage on their vehicles. Higher mileage values are associated with cars and larger vehicles such as SUV and van, but lower mileage values are associated with smaller cross utility vehicles and older vehicles.

As indicated earlier in the estimation section, the vehicle selection module of Figure 1 was estimated by pooling RC, SI and SP data. In such pooled estimations, one is often concerned with the possibility that the choice process exhibited in the RC data is different from that exhibited in the SI and SP data. For this reason, a scale parameter was estimated in the vehicle type choice - usage model to adjust model parameters in the joint RP-SI-SP model system. The RP to SI-SP scale parameter ( $\lambda$ ) was estimated to be 0.5538 with a t-statistic of 23.91 (against a value of 1 which corresponds to the case when the variance of unobserved factors in the RP and SI-SP contexts are equal). This scale parameter is significantly smaller than unity, indicating that the error variance in the SI-SP choice context is higher than in the RP choice context (see Borjesson (19) for similar result).

Among all the copula structures considered, the Frank copula model offered the best statistical fit based on the Bayesian Information Criterion (BIC) (20). The corresponding copula dependency parameter $(\theta)$ was estimated to be equal to -3.4097 with a t-statistic of -9.38 . This shows that there is significant dependency between the vehicle type choice and usage dimensions. The Kendall's measure $(\tau)$ which is similar to the standard correlation coefficient was computed using the expression:

$$
\tau=1-\frac{4}{\theta}\left[1-\frac{1}{\theta}\left[\int_{t=0}^{\theta} \frac{t}{e^{t}-1} d t\right]\right]
$$

The value of $\tau$ was found to be -0.3411 . The error term $v_{q i j}$ enters Equation (3) with a negative sign. Thus, a negative sign on the Kendall's measure indicates that the unobserved factors which increase the propensity to choose a certain vehicle type also increase the propensity to accumulate more mileage on that vehicle.

In terms of data fit, the log-likelihood value at convergence of an independent model that models vehicle type choice and usage separately was -29382.7. The Frank copula model, which offered the best statistical fit among all the joint copula model structures, had a log-likelihood value of -29187.20 The improvement in fit, relative to the independent model, is readily apparent and is highly statistically significant. To demonstrate that this improvement is not simply an artifact of overfitting, we undertook an additional evaluation exercise to test the comparative ability of the independent and joint models to replicate vehicle fleet composition choices in a random hold-out sample of 500 households not included in the estimation sample (see Table 3). The predicted log-likelihood function values of the independent and copula-based joint models were compared for different segments of the hold-out sample. The overall predictive log-likelihood ratio test values for comparing the copula based joint model with the independent model indicate that the copula based joint model is statistically significantly better than the independent model in all cases, except for households with no vehicles and households that have four or more workers where there is no appreciable difference in predictive power between the two models. The results clearly demonstrate the superiority of the joint model in predicting vehicle fleet composition and utilization, relative to the independent model. 


\subsection{Vehicle Evolution Models}

The vehicle evolution model component consists of an annual replacement decision model and an addition decision model. Estimation results for the replacement and addition models are presented in Tables $4 \mathrm{a}$ and $4 \mathrm{~b}$ respectively, and are discussed here.

The replacement model is a binary logit model that was found to offer plausible behavioral findings. The constant is significantly negative suggesting that households have a baseline preference to not replace their vehicles from one year to the next; this is consistent with the notion that vehicle transactions are infrequent events often spaced years apart. Caucasian and Hispanic households are more likely to replace a vehicle than households of other races. As expected, higher income households are more likely to replace a vehicle, while those with young children are less inclined to replace a vehicle. It is possible that households with young children are dealing with new expenses and do not feel the need to replace a vehicle. Households with older children are more likely to replace a vehicle, possibly because their fleet is getting old or because they are getting ready for the day when one or more children begins to drive. Small cross-utility vehicles are the least likely to be replaced; van, SUV, and pick-up truck are also not very likely to be replaced, and this reluctance to replace is particularly so for SUVs in large households. Among all body types, compact cars and cars (the base body type categories) are the most likely to be replaced. Older vehicles are more likely to be replaced than newer ones, although the coefficient for the 12 years or older category is less positive than for the 8-12 year old category. It is possible that vehicles 12 years or older have either been maintained very well, had parts replaced, or simply hold an emotional attachment that reduce the likelihood of replacement compared to the 8-12 year old category. Gasoline fuel vehicles are the most likely vehicle fuel type to be replaced, a finding consistent with the fact that gasoline vehicles are the predominant vehicle type in the population. Vehicles which are held for five or more years are most likely to be replaced, and the propensity to replace reduces (increases) as the duration of ownership decreases (increases). Finally, as expected, the results suggest important interdependencies in the transaction history. That is, the longer the duration (i.e., number of years) since any other vehicle in the household has been replaced or a vehicle has been added, the more likely that the household will replace a vehicle it currently holds (note that these variables are created based on the planned replacement or addition of vehicles, as obtained from the stated intentions data).

The vehicle addition model is also a binary logit model. Hispanic households are found to be the least likely to add a vehicle. Caucasians are found to be the second least likely to add a vehicle. Households with more adults and larger number of persons are more likely to add a new vehicle to their fleet. Lower income households are found to be more likely to add a vehicle in comparison to other higher income categories. It is possible that lower income households do not currently have the desired number of vehicles and hence desire to add a net additional vehicle to the fleet. Higher income households probably have the desired number of vehicles and so, rather than add a net additional vehicle, merely wish to replace an existing vehicle over time. Households with senior adults are less inclined to add a vehicle, while households with children aged 12-15 years are more likely to add a vehicle presumably because they are getting to acquire a vehicle for the new driver in the household. Households in rural regions appear more likely to add a vehicle. As current vehicle fleet size increases, the less likely it is for a household to add a net additional vehicle. This is true across all vehicle type categories. Finally, the results indicate that it is less likely to add a vehicle if a vehicle has been replaced recently. We could not include 
the effect of recent vehicle additions on the decision to add a vehicle because only eight households in the data indicated that they would add two new vehicles within the next five years.

The log-likelihood values at convergence of the replacement and addition models are -2675.62 and -428.88 respectively. The corresponding values for the "constant only" models are -2892.99 and -506.45 respectively. Clearly, one can reject the null hypothesis that none of the exogenous variables provide any value to predicting decision to replace/add a vehicle at any reasonable level of significance.

\section{CONCLUSIONS}

The modeling and analysis of household vehicle ownership and utilization by type of vehicle has gained added importance in recent years in the face of rising concerns about global energy sustainability, greenhouse gas (GHG) emissions, and community livability in urban areas around the world. Households may choose to own and drive (utilize) a variety of different vehicle types and the ability to accurately forecast these choice dimensions is undoubtedly of much interest in the current planning context which is dominated by efforts on the part of planners and policy makers to minimize the adverse impacts of automobile use on the environment.

This paper presents the design and formulation of a comprehensive vehicle fleet composition and evolution simulator that is capable of simulating household vehicle ownership and utilization decisions over time. The simulation framework consists of two main modules one module that models the current (baseline) fleet composition and utilization for a household and another module that evolves the baseline fleet over time by considering the acquisition, replacement, and disposal processes that households may undertake as they turnover their fleet.

One of the major impediments thus far to the development of such a vehicle fleet evolution simulation system has been the availability of longitudinal data on the dynamics of household vehicle ownership and utilization by type of vehicle. This issue is overcome in this study through the use of a large sample data set collected as part of a survey undertaken by the California Energy Commission in California. The survey includes a revealed choice (RC) component that captures information about current vehicle fleet information for the respondent households, a stated intentions (SI) component that captures information on the plans of respondent households to replace existing household vehicles or add net additional vehicles to the fleet (and the timing of such potential transactions), and a stated preference (SP) component that captures information on the vehicle type likely to be chosen by households when faced with a set of hypothetical choice scenarios. Data from these three survey components are pooled together to obtain a rich data set that can be used to model the full range of vehicle ownership and transactions decisions of households.

The paper includes a detailed description of the simulator framework, the modeling methodologies employed in various modules of the framework, and estimation results for various model components. In general, it is found that socio-economic characteristics, vehicular costs and performance measures, government incentives, and locational attributes are all important in predicting vehicle fleet composition, utilization, and evolution. The joint modeling framework is applied to predict vehicular choices for a random holdout sample of households and shown to perform substantially better than an independent set of model components that ignore common unobserved factors that impact both vehicle fleet composition and utilization.

The approach presented in this paper offers the ability to generate vehicle fleet composition and usage measures that serve as critical inputs to emissions forecasting models. The novelty of the approach is that it accommodates all of the dimensions characterizing vehicle 
fleet/usage decisions, as well as all of the dimensions of vehicle transactions (i.e., fleet evolution) over time. The resulting model can be used in a microsimulation-based forecasting model system to obtain the fleet composition for a future year and/or examine the effects of a host of policy variables aimed at promoting vehicle mix/usage patterns that reduce GHG emissions and fuel consumption. Further work involves the implementation of the vehicle simulator in the activitybased travel demand model system for the Southern California region.

\section{ACKNOWLEDGMENTS}

The authors would like to thank the California Energy Commission for providing access to the data used in this research, and the Southern California Association of Governments for facilitating this research. The authors are also grateful to Lisa Macias for her help in formatting this document. Five referees provided very useful comments on the earlier version of this paper. Finally, the authors acknowledge support from the Sustainable Cities Doctoral Research Initiative at the Center for Sustainable Development at The University of Texas at Austin. 


\section{REFERENCES}

1. Roorda, M. J., J. A. Carrasco, and E. J. Miller. An Integrated Model of Vehicle Transactions, Activity Scheduling and Mode Choice. Transportation Research Part B, Vol. 43, No. 2, 2008, pp. 217-229.

2. Fang, A. Discrete-Continuous Model of Households' Vehicle Choice and Usage, with an Application to the Effects of Residential Density. Transportation Research Part B, Vol. 42, No. 9, 2008, pp. 736-758.

3. Bhat, C. R., S. Sen, and N. Eluru. The Impact of Demographics, Built Environment Attributes, Vehicle Characteristics, and Gasoline Prices on Household Vehicle Holdings and Use. Transportation Research Part B, Vol. 43, No. 1, 2009, pp. 1-18.

4. Brownstone, D. and T. F. Golob. The Impact of Residential Density on Vehicle Usage and Energy Consumption. Journal of Urban Economics, Vol. 65, No. 1, 2009, pp. 91-98.

5. Hensher, D. A. and V. Le Plastrier. Towards a Dynamic Discrete-Choice Model of Household Automobile Fleet Size and Composition. Transportation Research Part B, Vol. 19, No. 6, 1985, pp. 481-495.

6. de Jong, G. and R. Kitamura. A Review of Household Dynamic Vehicle Ownership Models: Holdings Models versus Transactions Models. Proceedings of Seminar E, 20th PTRC Summer Annual Meeting, PTRC Education and Research Services Ltd., London, 1992, pp. 141-152.

7. Brownstone, D., D. S. Bunch, and K. Train. Joint Mixed Logit Models of Stated and Revealed Preferences for Alternative-Fuel Vehicles. Transportation Research Part B, Vol. 34, No. 5, 2000, pp. 315-338.

8. de Haan, P., M. G. Mueller, and R. W. Scholz. How Much do Incentives Affect Car Purchase? Agent-Based Microsimulation of Consumer Choice of New Cars, Part II: Forecasting effects of feebates based on energy-efficiency. Energy Policy, Vol. 37, No. 3, 2009, pp. 1083-1094.

9. Mueller, M. G. and P. de Haan. How Much do Incentives Affect Car Purchase? Agent-Based Microsimulation of Consumer Choice of New Cars, Part I: Model structure, simulation of bounded rationality, and model validation. Energy Policy, Vol. 37, No. 3, 2009, pp. 10721082.

10. Mohammadian, A. and E. J. Miller. Dynamic Modeling of Household Automobile Transactions. In Transportation Research Record: Journal of the Transportation Research Board, No. 1837, Transportation Research Board of the National Academies, Washington, D.C., 2003, pp. 98-105.

11. Yamamoto, T., R. Kitamura, and S. Kimura. Competing-Risks Duration Model of Household Vehicle Transactions with Indicators of Changes in Explanatory Variables. In Transportation Research Record: Journal of the Transportation Research Board, No. 1676, Transportation Research Board of the National Academies, Washington, D.C., 1999, pp. 116-123.

12. Prillwitz, J., S. Harms, M. Lanzendorf. Impact of Life-Course Events on Car Ownership. In Transportation Research Record: Journal of the Transportation Research Board, No. 1985, Transportation Research Board of the National Academies, Washington, D.C., 2006, pp. 7177.

13. Yamamoto, T. The Impact of Life Course Events on Vehicle Ownership Dynamics- The Cases of France and Japan. IATSS Research, Vol. 32, No. 2, 2008, pp. 34-43. 
14. de Jong, G. C., J. Fox, A. Daly, M. Pieters, R. Smit. A Comparison of Car Ownership Models. Transport Reviews, Vol. 24, No. 4, 2004, pp. 379-408.

15. Bunch, D. S. Automobile Demand and Type Choice. In D. A. Hensher and K. J. Button (Eds) Handbook of Transport Modelling, pp. 463-479, Pergamon, Oxford, 2000.

16. Eluru, N., C. R. Bhat, R. M. Pendyala, and K. C. Konduri. A Joint Flexible Econometric Model System of Household Residential Location and Vehicle Fleet Composition/Usage Choices. Transportation, Vol. 37, No. 4, 2010, pp. 603-626.

17. Lee L. F. Generalized Econometric Models with Selectivity. Econometrica, Vol. 51, No. 2, 1983, pp. 507-512.

18. Bhat, C. R. and N. Eluru. A Copula-Based Approach to Accommodate Residential SelfSelection Effects in Travel Behavior Modeling. Transportation Research Part B, Vol. 43, No. 7, 2009, pp. 749-765.

19. Borjesson, M. Joint RP-SP Data in a Mixed Logit Analysis of Trip Timing Decisions. Transportation Research Part E, Vol. 44, No. 6, 2008, pp. 1025-1038.

20. Trivedi, P. K. and D. M. Zimmer. Copula Modeling: An Introduction for Practitioners. Foundations and Trends in Econometrics, Vol. 1, No. 1, Now Publishers, Inc., 2007. 


\section{LIST OF TABLES}

TABLE 1 Sample Characteristics

TABLE 2a Estimates of the Vehicle Type Choice Component of Vehicle Selection Module

TABLE 2b Estimates of the Vehicle Usage Component of Vehicle Selection Module

TABLE 3 Disaggregate Measures of Fit for the Validation Sample

TABLE 4a Replacement Decision of Evolution Module: Binary Logit Model

TABLE 4b Addition Decision of Evolution Module: Binary Logit Model

\section{LIST OF FIGURES}

FIGURE 1 Vehicle fleet composition, utilization, and evolution simulator framework. 
TABLE 1 Sample Characteristics

\begin{tabular}{|c|c|c|}
\hline Variable & Sample Share (\%) & Mean Mileage \\
\hline \multicolumn{3}{|l|}{ Vehicle Type } \\
\hline Compact Car & 25.6 & 11894.36 \\
\hline Car & 29.3 & 11887.08 \\
\hline Small Cross-utility Vehicle & 4.8 & 11612.97 \\
\hline SUV & 18.5 & 13099.24 \\
\hline Van & 5.9 & 13019.13 \\
\hline Pickup & 16.0 & 12310.61 \\
\hline \multicolumn{3}{|l|}{ Number of vehicles } \\
\hline Zero & 1.8 & \\
\hline One & 28.4 & \\
\hline Two & 50.0 & \\
\hline Three & 14.2 & \\
\hline Four or more & 5.6 & \\
\hline \multicolumn{3}{|l|}{ Number of adults } \\
\hline One & 18.5 & \\
\hline Two & 64.3 & \\
\hline Three & 10.7 & \\
\hline Four & 4.9 & \\
\hline Five or more & 1.5 & \\
\hline \multicolumn{3}{|l|}{ Number of workers } \\
\hline Zero & 18.3 & \\
\hline One & 34.5 & \\
\hline Two & 39.8 & \\
\hline Three & 5.5 & \\
\hline Four or more & 1.9 & \\
\hline \multicolumn{3}{|l|}{ Location } \\
\hline Urban & 48.2 & \\
\hline Suburban & 47.8 & \\
\hline Rural & 4.0 & \\
\hline Presence of senior adults & 22.1 & \\
\hline \multicolumn{3}{|l|}{ Presence of children } \\
\hline $0-4$ years & 12.8 & \\
\hline 5-11 years & 14.9 & \\
\hline 12 to 15 years & 10.4 & \\
\hline \multicolumn{3}{|l|}{ Household Income } \\
\hline$<\$ 20 \mathrm{k}$ & 3.3 & \\
\hline Between $\$ 20$ and $\$ 40 \mathrm{~K}$ & 13.1 & \\
\hline Between $\$ 40$ and $\$ 60 \mathrm{~K}$ & 16.0 & \\
\hline Between $\$ 60 \mathrm{~K}$ and $80 \mathrm{~K}$ & 18.3 & \\
\hline Between $\$ 80 \mathrm{~K}$ and $\$ 100 \mathrm{~K}$ & 14.8 & \\
\hline Between $\$ 100 \mathrm{~K}$ and $\$ 120 \mathrm{~K}$ & 10.8 & \\
\hline$>\$ 120 \mathrm{~K}$ & 23.7 & \\
\hline \multicolumn{3}{|l|}{ Educational Attainment } \\
\hline High school & 8.2 & \\
\hline College (with/without degree) & 58.0 & \\
\hline Post Graduate & 33.8 & \\
\hline Total Sample Size & 1165 & \\
\hline
\end{tabular}




\section{Base year}

-Number of vehicles

-Type of each vehicle

-Fuel type of each vehicle

-Vintage of each vehicle

-Mileage of each vehicle

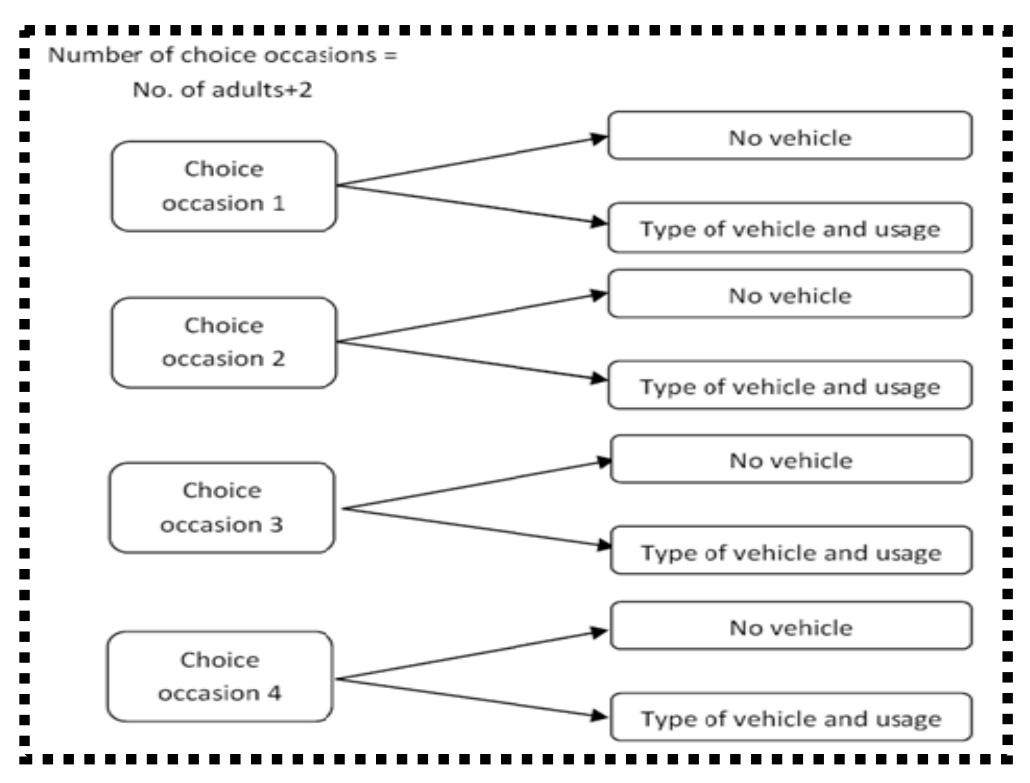

\section{Evolution year}

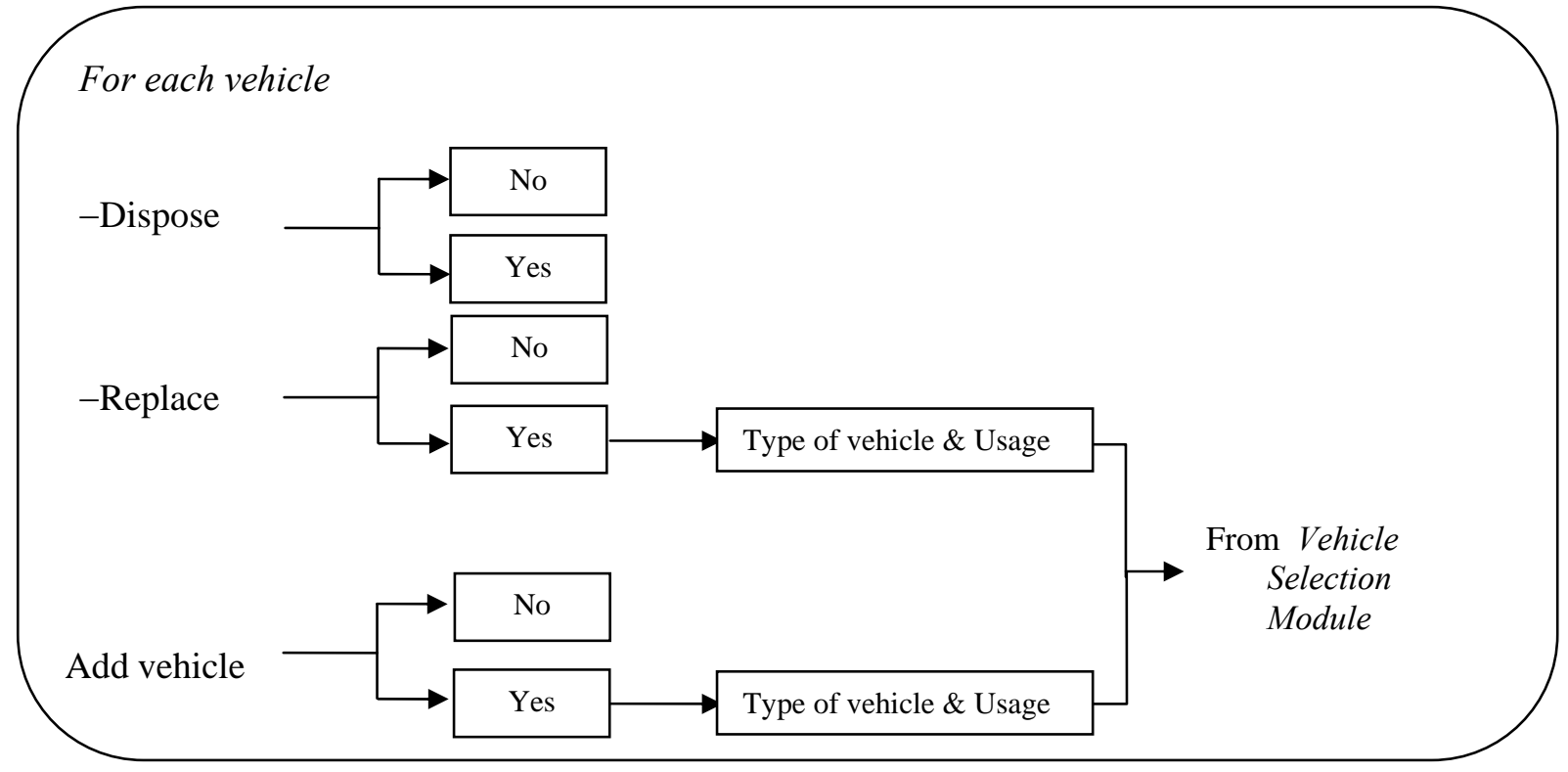

Vehicle Selection Module

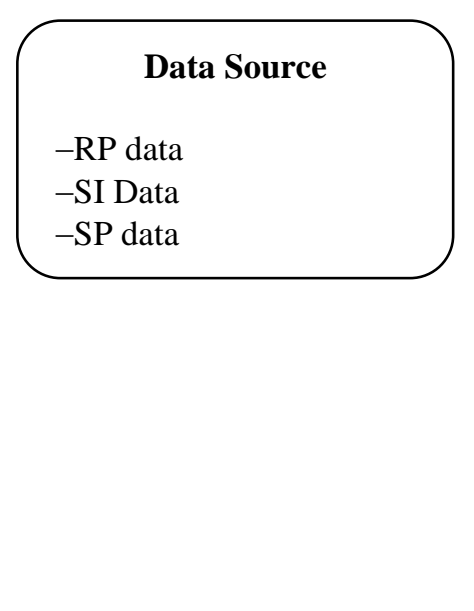

FIGURE 1 Vehicle fleet composition, utilization, and evolution simulator framework.

Data Source

-SI data 
TABLE 2a Estimates of the Vehicle Type Choice Component of Vehicle Selection Module

\begin{tabular}{|c|c|c|c|c|c|c|c|c|c|}
\hline \multirow{3}{*}{ Variable } & \multirow{3}{*}{ Constant } & \multicolumn{8}{|c|}{ Generic Effects } \\
\hline & & \multicolumn{4}{|c|}{ Cost Variables } & \multicolumn{2}{|c|}{ Vehicle Performance } & \multicolumn{2}{|c|}{ Incentives } \\
\hline & & $\begin{array}{c}\text { Purchase } \\
\text { Price*10,000 (\$) }\end{array}$ & $\begin{array}{l}\text { Fuel cost per } \\
\text { gallon (\$) }\end{array}$ & $\begin{array}{c}\text { Fuel cost per } \\
\text { year } / 10,000(\$)\end{array}$ & $\begin{array}{c}\text { Maintenance } \\
\text { cost per } \\
\text { year } / 1000(\$)\end{array}$ & \begin{tabular}{|c|}
$\begin{array}{c}\text { Acceleration } \\
\text { Time }\end{array}$ \\
(0 to $60 \mathrm{mph}$ )
\end{tabular} & $\begin{array}{c}\text { Miles per } \\
\text { Gallon } \\
/ 100 \\
\end{array}$ & Car pooling & $\begin{array}{c}\text { Free } \\
\text { parking }\end{array}$ \\
\hline No vehicle & $\begin{array}{l}-- \\
--\end{array}$ & $\begin{array}{l}-- \\
--\end{array}$ & $\begin{array}{l}-- \\
--\end{array}$ & $\begin{array}{l}- \\
--\end{array}$ & $\begin{array}{l}- \\
--\end{array}$ & $\begin{array}{l}- \\
--\end{array}$ & $\begin{array}{l}-- \\
--\end{array}$ & $\begin{array}{l}-- \\
--\end{array}$ & $\begin{array}{l}-- \\
--\end{array}$ \\
\hline Compact Car (CC) & $\begin{array}{c}-0.9371 \\
(-5.95)\end{array}$ & & & & & & & & \\
\hline & $\begin{array}{c}-1.3264 \\
(-9.05)\end{array}$ & & & & & & & & \\
\hline Small cross utility vehicle (SCU) & $\begin{array}{l}-2.8986 \\
(-14.28)\end{array}$ & & & & & & & & \\
\hline SUV & $\begin{array}{l}-2.5797 \\
(-15.38)\end{array}$ & & & & & & & & \\
\hline Van & $\begin{array}{l}-3.5886 \\
(-10.66)\end{array}$ & & & & & & & & \\
\hline Pickup & $\begin{array}{l}-2.0160 \\
(-11.89)\end{array}$ & & & & & & & & \\
\hline & $\begin{array}{l}-- \\
--\end{array}$ & & & & & & & & \\
\hline Flex Fuel & $\begin{array}{l}-6.2144 \\
(-24.53)\end{array}$ & & & & & & & & \\
\hline Plug-in Hybrid & -6.4622 & & & & & & & & \\
\hline CNG & $\begin{array}{c}(-16.20) \\
-10.1330 \\
(-12.47)\end{array}$ & $\begin{array}{l}-0.6950 \\
(-18.90)\end{array}$ & $\begin{array}{c}-0.1469 \\
(-1.86)\end{array}$ & $\begin{array}{l}-4.7015 \\
(-10.22)\end{array}$ & $\begin{array}{c}-0.4843 \\
(-2.35)\end{array}$ & $\begin{array}{c}-0.0424 \\
(-3.12)\end{array}$ & $\begin{array}{l}4.8838 \\
(13.59)\end{array}$ & $\begin{array}{l}1.3079 \\
(11.34)\end{array}$ & $\begin{array}{c}1.4419 \\
(12.19)\end{array}$ \\
\hline Diesel & $\begin{array}{l}-4.3522 \\
(-18.67)\end{array}$ & & & & & & & & \\
\hline Hybrid Electric (HE) & $\begin{array}{l}-4.1772 \\
(-23.36)\end{array}$ & & & & & & & & \\
\hline Fully Electric (FE) & $\begin{array}{l}-9.2407 \\
(-12.46)\end{array}$ & & & & & & & & \\
\hline & -- & & & & & & & & \\
\hline 1 or 2 years & $\begin{array}{c}-1.9193 \\
(-7.53)\end{array}$ & & & & & & & & \\
\hline 3 to 7 years & $\begin{array}{l}-1.3114 \\
(-13.38)\end{array}$ & & & & & & & & \\
\hline 8 to 12 years & $\begin{array}{l}-3.1988 \\
(-17.45)\end{array}$ & & & & & & & & \\
\hline$>12$ years & $\begin{array}{l}-3.8380 \\
(-14.78)\end{array}$ & & & & & & & & \\
\hline
\end{tabular}


Paleti, Eluru, Bhat, Pendyala, Adler, and Goulias

TABLE 2a Estimates of the Vehicle Type Choice Component of Vehicle Selection Module (Continued)

\begin{tabular}{|c|c|c|c|c|c|c|c|c|c|c|c|c|}
\hline \multirow{3}{*}{ Variable $\rightarrow$} & \multirow{2}{*}{\multicolumn{3}{|c|}{$\begin{array}{c}\text { Generic Effects } \\
\text { Incentives } \\
\end{array}$}} & \multirow{2}{*}{\multicolumn{3}{|c|}{ Fuel Infrastructure/Vehicle Range }} & \multicolumn{6}{|c|}{ Demographics } \\
\hline & & & & & & & \multirow{2}{*}{$\begin{array}{c}\text { Number } \\
\text { of male } \\
\text { adults } \\
\text { (>=16 } \\
\text { years) }\end{array}$} & \multirow{2}{*}{$\begin{array}{c}\text { Number } \\
\text { of female } \\
\text { adults } \\
\text { (>=16 } \\
\text { years) }\end{array}$} & \multicolumn{4}{|c|}{ Household Income } \\
\hline & $\begin{array}{c}\$ 1,000 \\
\text { Tax } \\
\text { credits }\end{array}$ & $\begin{array}{c}50 \% \\
\text { Reduced } \\
\text { toll }\end{array}$ & $\begin{array}{c}\$ 1,000 \\
\text { Vehicle } \\
\text { price } \\
\text { reduction }\end{array}$ & $\begin{array}{c}\text { Fuel } \\
\text { availability } \\
(1 \text { in } 50 \\
\text { stations })\end{array}$ & $\begin{array}{c}\text { Vehicle } \\
\text { range }(150 \\
\text { to } 200 \\
\text { miles) }\end{array}$ & $\begin{array}{l}\text { Vehicle } \\
\text { range } \\
\text { (>200 } \\
\text { miles) }\end{array}$ & & & $<\$ 20 K$ & $(\$ 20 \mathrm{~K}, \$ 40 \mathrm{~K})$ & $(\$ 40 K, \$ 60 K)$ & $(\$ 60 \mathrm{~K}, \$ 80 \mathrm{~K})$ \\
\hline No vehicle & $\begin{array}{l}- \\
--\end{array}$ & $\begin{array}{l}- \\
--\end{array}$ & $\begin{array}{l}-- \\
--\end{array}$ & $\begin{array}{l}-- \\
--\end{array}$ & $\begin{array}{l}- \\
--\end{array}$ & $\begin{array}{l}-- \\
--\end{array}$ & $\begin{array}{l}- \\
--\end{array}$ & $\begin{array}{l}- \\
--\end{array}$ & $\begin{array}{l}-- \\
--\end{array}$ & $\begin{array}{l}-- \\
--\end{array}$ & $\begin{array}{l}- \\
--\end{array}$ & $\begin{array}{l}-- \\
--\end{array}$ \\
\hline CC & & & & -- & -- & -- & -- & -- & -- & -- & -- & 0.5159 \\
\hline & & & & -- & -- & -- & -- & -- & -- & -- & -- & $(4.67)$ \\
\hline Car & & & & -- & -- & -- & 0.4800 & -- & -- & -- & 0.5436 & 1.1559 \\
\hline & & & & -- & -- & -- & $(7.60)$ & -- & -- & -- & $(4.01)$ & (8.49) \\
\hline \multirow[t]{2}{*}{ SCU } & & & & -- & -- & -- & -- & -- & -- & -- & -- & $0 . .9642$ \\
\hline & & & & -- & -- & -- & -- & -- & -- & -- & -- & $(5.32)$ \\
\hline \multirow[t]{2}{*}{ SUV } & & & & -- & -- & -- & 0.3614 & 0.3614 & -- & -- & 0.3895 & 1.3496 \\
\hline & & & & -- & -- & -- & $(7.85)$ & $(7.85)$ & -- & -- & $(2.31)$ & $(8.82)$ \\
\hline \multirow[t]{2}{*}{ Van } & & & & -- & -- & -- & 0.5299 & -- & -- & -- & -- & 0.5645 \\
\hline & & & & -- & -- & -- & $(4.02)$ & -- & -- & -- & -- & (3.56) \\
\hline Pickup & & & & -- & -- & $\begin{array}{l}-- \\
--\end{array}$ & $\begin{array}{c}0.6896 \\
(8.28)\end{array}$ & $\begin{array}{l}-- \\
--\end{array}$ & $\begin{array}{l}-- \\
--\end{array}$ & -- & $\begin{array}{c}0.5322 \\
(3.29)\end{array}$ & $\begin{array}{c}0.8608 \\
(5.60)\end{array}$ \\
\hline \multirow{2}{*}{ Gasoline } & & & & -- & -- & -- & -- & -- & -- & -- & -- & -- \\
\hline & & & & -- & -- & -- & -- & -- & -- & -- & -- & -- \\
\hline \multirow{2}{*}{ Flex Fuel } & & & & -- & -- & -- & -- & -- & 0.5122 & 0.5122 & -- & -- \\
\hline & & & & & -- & -- & $\begin{array}{l}-- \\
-1\end{array}$ & -- & (2.37) & (2.37) & -- & -- \\
\hline Plug-in & & & & -- & -- & -- & -0.5595 & -- & -0.4032 & -- & -- & -- \\
\hline \multirow{2}{*}{ CNG } & 1.5135 & 1.1110 & 1.2653 & $\begin{array}{c}-- \\
-0 \\
-0\end{array}$ & 46639 & $\overline{8}-\overline{-}$ & $(-8.11)$ & -- & $(-1.52)$ & -- & -- & -- \\
\hline & $(17.74)$ & $(9.83)$ & $\begin{array}{l}1.2053 \\
(10.53)\end{array}$ & $\begin{array}{c}-0.3278 \\
(-1.48)\end{array}$ & $\begin{array}{c}4.6639 \\
(5.49)\end{array}$ & $\begin{array}{l}4.8415 \\
(5.88)\end{array}$ & $\begin{array}{l}-- \\
--\end{array}$ & -- & & $\begin{array}{l}-- \\
--\end{array}$ & $\begin{array}{l}-- \\
--\end{array}$ & $\begin{array}{l}-- \\
--\end{array}$ \\
\hline \multirow[t]{2}{*}{ Diesel } & & & & -- & -- & -- & -- & -0.4497 & -0.9198 & -0.9198 & -- & -- \\
\hline & & & & -- & -- & -- & -- & $(-4.06)$ & $(-5.08)$ & $(-5.08)$ & -- & -- \\
\hline $\mathrm{HE}$ & & & & $\begin{array}{l}-- \\
--\end{array}$ & -- & -- & $\begin{array}{r}-0.5595 \\
(-811)\end{array}$ & -- & -- & -- & -- & 0.3078 \\
\hline FE & & & & $\begin{array}{c}-- \\
-0.3278\end{array}$ & 4.6639 & 4.8415 & $\begin{array}{c}(-8.11) \\
--\end{array}$ & $0 . \overline{4141}$ & $\begin{array}{l}-- \\
--\end{array}$ & $\begin{array}{l}-- \\
--\end{array}$ & $\begin{array}{l}-- \\
--\end{array}$ & (2.88) \\
\hline & & & & $(-1.48)$ & (5.49) & (5.88) & -- & $(2.84)$ & -- & -- & -- & -- \\
\hline New Car & & & & -- & -- & -- & -- & -- & -- & -- & -- & -- \\
\hline 1 or 2 years & & & & $\begin{array}{l}-- \\
--\end{array}$ & -- & $\begin{array}{l}-- \\
--\end{array}$ & $\begin{array}{l}-- \\
--\end{array}$ & -- & $\begin{array}{l}-- \\
--\end{array}$ & 0.5852 & 0.5852 & 0.5852 \\
\hline & & & & -- & -- & -- & -- & -- & -- & $(2.30)$ & $(2.30)$ & $(2.30)$ \\
\hline 3 to 7 years & & & & -- & -- & -- & -- & -- & -- & 0.5852 & 0.5852 & 0.5852 \\
\hline & & & & -- & -- & -- & -- & -- & -- & $(2.30)$ & $(2.30)$ & $(2.30)$ \\
\hline 8 to 12 yrs & & & & -- & -- & -- & -- & -- & -- & 0.9603 & 0.6543 & -- \\
\hline & & & & -- & -- & -- & -- & -- & -- & $(6.71)$ & $(4.35)$ & -- \\
\hline$>12$ years & & & & -- & -- & -- & 0.5111 & -- & -- & 0.9603 & 0.6543 & -- \\
\hline & & & & -- & -- & -- & (3.17) & -- & -- & $(6.71)$ & $(4.35)$ & -- \\
\hline
\end{tabular}


TABLE 2a Estimates of the Vehicle Type Choice Component of Vehicle Selection Module (Continued)

\begin{tabular}{|c|c|c|c|c|c|c|c|c|c|c|c|}
\hline \multirow{3}{*}{ Variable $\rightarrow$} & \multicolumn{11}{|c|}{ Demographics } \\
\hline & \multicolumn{3}{|c|}{ Household Income } & \multicolumn{2}{|c|}{ Residential Location } & \multicolumn{2}{|c|}{ Education Attainment } & \multicolumn{3}{|c|}{ Presence of children } & \multirow{2}{*}{$\begin{array}{c}\text { Presence of } \\
\text { senior } \\
\text { adults ( }>65 \\
\text { years) }\end{array}$} \\
\hline & $(\$ 80 K, \$ 100 K)$ & $(\$ 100 K, \$ 120 K)$ & $>\$ 120 \mathrm{~K}$ & Sub-urban & Rural & College & $\begin{array}{c}\text { Post } \\
\text { graduate }\end{array}$ & $\begin{array}{l}0 \text { to } 4 \\
\text { years }\end{array}$ & $\begin{array}{c}5 \text { to } 11 \\
\text { years }\end{array}$ & $\begin{array}{c}12 \text { to } 15 \\
\text { years }\end{array}$ & \\
\hline No vehicle & $\begin{array}{l}-- \\
--\end{array}$ & $\begin{array}{l}-- \\
--\end{array}$ & $\begin{array}{l}-- \\
--\end{array}$ & $\begin{array}{l}-- \\
--\end{array}$ & $\begin{array}{l}-- \\
--\end{array}$ & $\begin{array}{l}-- \\
--\end{array}$ & $\begin{array}{l}-- \\
--\end{array}$ & $\begin{array}{l}-- \\
--\end{array}$ & $\begin{array}{l}-- \\
--\end{array}$ & $\begin{array}{l}-- \\
--\end{array}$ & $\begin{array}{l}-- \\
--\end{array}$ \\
\hline CC & $\begin{array}{c}0.5159 \\
(4.67)\end{array}$ & $\begin{array}{c}0.5159 \\
(4.67)\end{array}$ & $\begin{array}{c}0.8126 \\
(6.64)\end{array}$ & $\begin{array}{l}-- \\
--\end{array}$ & $\begin{array}{l}-- \\
--\end{array}$ & $\begin{array}{c}0.3971 \\
(2.89)\end{array}$ & $\begin{array}{c}0.5958 \\
(4.17)\end{array}$ & $\begin{array}{c}-0.2360 \\
(-1.86)\end{array}$ & $\begin{array}{l}-- \\
--\end{array}$ & $\begin{array}{l}-- \\
--\end{array}$ & $\begin{array}{l}-- \\
--\end{array}$ \\
\hline Car & $\begin{array}{l}1.1559 \\
(8.49)\end{array}$ & $\begin{array}{l}1.1559 \\
(8.49)\end{array}$ & $\begin{array}{l}1.6302 \\
(11.19)\end{array}$ & $\begin{array}{l}-- \\
--\end{array}$ & $\begin{array}{l}-- \\
--\end{array}$ & -- & -- & -- & $\begin{array}{l}-- \\
--\end{array}$ & $\begin{array}{l}-- \\
--\end{array}$ & $\begin{array}{c}0.4286 \\
(5.05)\end{array}$ \\
\hline SCU & $\begin{array}{c}0 . .9642 \\
(5.32)\end{array}$ & $\begin{array}{c}0 . .9642 \\
(5.32)\end{array}$ & $\begin{array}{l}1.8321 \\
(9.56)\end{array}$ & $\begin{array}{l}-- \\
--\end{array}$ & $\begin{array}{l}-- \\
--\end{array}$ & $\begin{array}{l}0.4175 \\
(3.05)\end{array}$ & $\begin{array}{l}-- \\
--\end{array}$ & $\begin{array}{l}-- \\
--\end{array}$ & $\begin{array}{c}-0.8584 \\
(-3.85)\end{array}$ & $\begin{array}{l}-- \\
--\end{array}$ & -- \\
\hline SUV & $\begin{array}{l}1.3496 \\
(8.82)\end{array}$ & $\begin{array}{l}1.4079 \\
(8.04)\end{array}$ & $\begin{array}{l}1.8423 \\
(11.28)\end{array}$ & $\begin{array}{c}0.2403 \\
(3.31)\end{array}$ & $\begin{array}{l}-- \\
--\end{array}$ & $\begin{array}{c}0.1471 \\
(1.84)\end{array}$ & $\begin{array}{l}-- \\
--\end{array}$ & $\begin{array}{c}0.5392 \\
(5.12)\end{array}$ & -- & $\begin{array}{l}-- \\
--\end{array}$ & $\begin{array}{l}-- \\
--\end{array}$ \\
\hline Van & $\begin{array}{l}0.5645 \\
(3.56)\end{array}$ & $\begin{array}{l}0.5645 \\
(3.56)\end{array}$ & $\begin{array}{l}0.5645 \\
(3.56)\end{array}$ & $\begin{array}{l}-- \\
--\end{array}$ & $\begin{array}{l}-- \\
--\end{array}$ & $\begin{array}{l}0.6999 \\
(2.44)\end{array}$ & $\begin{array}{l}1.0881 \\
(3.60)\end{array}$ & $\begin{array}{l}1.1014 \\
(6.87)\end{array}$ & $\begin{array}{l}-- \\
--\end{array}$ & $\begin{array}{l}-- \\
--\end{array}$ & $\begin{array}{l}-- \\
--\end{array}$ \\
\hline Pickup & $\begin{array}{c}0.8608 \\
(5.60) \\
\end{array}$ & $\begin{array}{c}0.7988 \\
(4.89) \\
\end{array}$ & $\begin{array}{c}0.7988 \\
(4.89) \\
\end{array}$ & $\begin{array}{c}0.5671 \\
(5.98) \\
\end{array}$ & $\begin{array}{r}0.8937 \\
(3.96) \\
\end{array}$ & $\begin{array}{l}-- \\
-- \\
\end{array}$ & $\begin{array}{c}-0.6031 \\
(-5.16) \\
\end{array}$ & -- & $\begin{array}{l}-- \\
--\end{array}$ & $\begin{array}{l}-- \\
-- \\
\end{array}$ & $\begin{array}{l}-- \\
--\end{array}$ \\
\hline Gasoline & $\begin{array}{l}-- \\
--\end{array}$ & $\begin{array}{l}- \\
--\end{array}$ & $\begin{array}{l}- \\
--\end{array}$ & $\begin{array}{l}- \\
--\end{array}$ & $\begin{array}{l}- \\
--\end{array}$ & $\begin{array}{l}-- \\
--\end{array}$ & & $\begin{array}{l}-- \\
--\end{array}$ & $\begin{array}{l}-- \\
--\end{array}$ & $\begin{array}{l}-- \\
--\end{array}$ & $\begin{array}{l}-- \\
--\end{array}$ \\
\hline Flex Fuel & $\begin{array}{l}-- \\
--\end{array}$ & $\begin{array}{l}-- \\
--\end{array}$ & $\begin{array}{l}-- \\
--\end{array}$ & $\begin{array}{c}-0.2421 \\
(-1.60)\end{array}$ & $\begin{array}{l}-- \\
--\end{array}$ & -- & $\begin{array}{c}0.3105 \\
(1.89)\end{array}$ & -- & $\begin{array}{l}-- \\
--\end{array}$ & $\begin{array}{l}-- \\
--\end{array}$ & $\begin{array}{c}-0.3524 \\
(-1.88)\end{array}$ \\
\hline Plug-in & $\begin{array}{l}-- \\
--\end{array}$ & $\begin{array}{l}-- \\
--\end{array}$ & $\begin{array}{l}-- \\
--\end{array}$ & $\begin{array}{c}-0.3294 \\
(-2.97)\end{array}$ & $\begin{array}{l}-- \\
--\end{array}$ & $\begin{array}{c}0.7447 \\
(2.63)\end{array}$ & $\begin{array}{l}1.4357 \\
(4.78)\end{array}$ & -- & $\begin{array}{l}-- \\
--\end{array}$ & -- & -- \\
\hline CNG & -- & -- & -- & -- & -- & -- & -- & -- & -- & -- & -- \\
\hline Diesel & $\begin{array}{l}-- \\
--\end{array}$ & $\begin{array}{l}-- \\
--\end{array}$ & $\begin{array}{l}-- \\
--\end{array}$ & $\begin{array}{l}-- \\
--\end{array}$ & $\begin{array}{l}1.4089 \\
(5.88)\end{array}$ & $\begin{array}{c}-0.2817 \\
(-2.52)\end{array}$ & $\begin{array}{l}-- \\
--\end{array}$ & $\begin{array}{c}-0.4497 \\
(-2.52)\end{array}$ & $\begin{array}{l}-- \\
--\end{array}$ & $\begin{array}{c}0.3664 \\
(2.42)\end{array}$ & $\begin{array}{l}-- \\
--\end{array}$ \\
\hline $\mathrm{HE}$ & $\begin{array}{l}0.3078 \\
(2.88)\end{array}$ & $\begin{array}{l}0.3078 \\
(2.88)\end{array}$ & $\begin{array}{l}0.3078 \\
(2.88)\end{array}$ & $\begin{array}{c}-0.4084 \\
(-4.71)\end{array}$ & $\begin{array}{c}0.6959 \\
(2.24)\end{array}$ & -- & $\begin{array}{l}0.6418 \\
(6.70)\end{array}$ & $\begin{array}{l}-- \\
--\end{array}$ & $\begin{array}{l}-- \\
--\end{array}$ & -- & $\begin{array}{l}0.3447 \\
(3.49)\end{array}$ \\
\hline FE & $\begin{array}{l}-- \\
-- \\
\end{array}$ & $\begin{array}{l}-- \\
-- \\
\end{array}$ & & $\begin{array}{r}-0.6467 \\
(-4.04) \\
\end{array}$ & $\begin{array}{l}-- \\
-- \\
\end{array}$ & $\begin{array}{l}1.5261 \\
(2.56) \\
\end{array}$ & $\begin{array}{l}1.6286 \\
(2.69)\end{array}$ & $\begin{array}{c}0.7100 \\
(3.66)\end{array}$ & $\begin{array}{l}-- \\
--\end{array}$ & $\begin{array}{l}-- \\
--\end{array}$ & $\begin{array}{l}-- \\
--\end{array}$ \\
\hline New Car & $\begin{array}{l}0.8084 \\
(13.27)\end{array}$ & $\begin{array}{l}0.8084 \\
(13.27)\end{array}$ & $\begin{array}{l}0.8084 \\
(13.27)\end{array}$ & $\begin{array}{l}-- \\
--\end{array}$ & $\begin{array}{l}-- \\
--\end{array}$ & $\begin{array}{c}0.2344 \\
(3.44)\end{array}$ & $\begin{array}{l}-- \\
--\end{array}$ & $\begin{array}{l}-- \\
--\end{array}$ & $\begin{array}{l}-- \\
--\end{array}$ & $\begin{array}{l}-- \\
--\end{array}$ & $\begin{array}{l}-- \\
--\end{array}$ \\
\hline 1 or 2 years & $\begin{array}{l}1.0202 \\
(3.90)\end{array}$ & $\begin{array}{l}1.0202 \\
(3.90)\end{array}$ & $\begin{array}{l}1.0202 \\
(3.90)\end{array}$ & $\begin{array}{l}-- \\
--\end{array}$ & $\begin{array}{l}-- \\
--\end{array}$ & -- & $\begin{array}{c}-0.4539 \\
(-5.94)\end{array}$ & $\begin{array}{l}-- \\
--\end{array}$ & $\begin{array}{l}-- \\
--\end{array}$ & -- & -- \\
\hline 3 to 7 years & -- & -- & $\begin{array}{l}-- \\
--\end{array}$ & $\begin{array}{l}-- \\
--\end{array}$ & $\begin{array}{l}-- \\
--\end{array}$ & $\begin{array}{l}-- \\
--\end{array}$ & $\begin{array}{c}-0.4539 \\
(-5.94)\end{array}$ & -- & $\begin{array}{l}-- \\
--\end{array}$ & $\begin{array}{c}0.3980 \\
(4.74)\end{array}$ & $\begin{array}{c}-0.5208 \\
(-6.26)\end{array}$ \\
\hline 8 to $12 \mathrm{yrs}$ & $\begin{array}{l}-- \\
--\end{array}$ & $\begin{array}{l}-- \\
--\end{array}$ & $\begin{array}{c}-0.7240 \\
(-3.83)\end{array}$ & $\begin{array}{l}-- \\
--\end{array}$ & $\begin{array}{l}-- \\
--\end{array}$ & $\begin{array}{l}-- \\
--\end{array}$ & $\begin{array}{c}-0.4539 \\
(-5.94)\end{array}$ & $\begin{array}{l}-- \\
--\end{array}$ & $\begin{array}{c}-0.5472 \\
(-3.10)\end{array}$ & $\begin{array}{c}0.3980 \\
(4.74)\end{array}$ & $\begin{array}{c}-0.5208 \\
(-6.26)\end{array}$ \\
\hline$>12$ years & $\begin{array}{l}-- \\
--\end{array}$ & $\begin{array}{l}-- \\
--\end{array}$ & $\begin{array}{c}-0.7240 \\
(-3.83)\end{array}$ & $\begin{array}{l}-- \\
--\end{array}$ & $\begin{array}{l}-- \\
--\end{array}$ & $\begin{array}{l}-- \\
--\end{array}$ & $\begin{array}{c}-0.4539 \\
(-5.94)\end{array}$ & $\begin{array}{l}-- \\
--\end{array}$ & $\begin{array}{c}-0.5472 \\
(-3.10)\end{array}$ & $\begin{array}{c}0.3980 \\
(4.74)\end{array}$ & $\begin{array}{c}-0.5208 \\
(-6.26)\end{array}$ \\
\hline
\end{tabular}


TABLE 2a Estimates of the Vehicle Type Choice Component of Vehicle Selection Module (Continued)

\begin{tabular}{|c|c|c|c|c|c|c|c|c|c|c|c|}
\hline \multirow{3}{*}{ Variable $\rightarrow$} & \multicolumn{5}{|c|}{ Demographics } & \multirow{2}{*}{\multicolumn{6}{|c|}{ Existing Fleet Characteristics }} \\
\hline & \multirow[b]{2}{*}{ Caucasian } & \multicolumn{4}{|c|}{ Number of workers } & & & & & & \\
\hline & & $\begin{array}{l}\text { \# full time } \\
\text { workers }\end{array}$ & $\begin{array}{l}\text { \# part time } \\
\text { workers }\end{array}$ & $\begin{array}{c}\text { \# full time } \\
\text { workers from } \\
\text { home }\end{array}$ & $\begin{array}{c}\text { \# part time } \\
\text { workers from } \\
\text { home }\end{array}$ & $\begin{array}{c}\text { Presence } \\
\text { of CC }\end{array}$ & $\begin{array}{c}\text { Presence } \\
\text { of Car }\end{array}$ & $\begin{array}{l}\text { Presence } \\
\text { of SCU }\end{array}$ & $\begin{array}{l}\text { Presence } \\
\text { of SUV }\end{array}$ & $\begin{array}{c}\text { Presence } \\
\text { of Van }\end{array}$ & $\begin{array}{l}\text { Presence } \\
\text { of pickup }\end{array}$ \\
\hline No vehicle & $\begin{array}{l}-- \\
--\end{array}$ & $\begin{array}{l}-- \\
--\end{array}$ & $\begin{array}{l}-- \\
--\end{array}$ & $\begin{array}{l}-- \\
--\end{array}$ & $\begin{array}{l}- \\
--\end{array}$ & $\begin{array}{l}-- \\
--\end{array}$ & $\begin{array}{l}-- \\
--\end{array}$ & $\begin{array}{l}-- \\
--\end{array}$ & $\begin{array}{l}-- \\
--\end{array}$ & $\begin{array}{l}- \\
--\end{array}$ & $\begin{array}{l}-- \\
--\end{array}$ \\
\hline CC & 0.1266 & $\begin{array}{l}-- \\
--\end{array}$ & $\begin{array}{l}-- \\
--\end{array}$ & $\begin{array}{l}-- \\
--\end{array}$ & 0.2752 & $\begin{array}{l}-1.9803 \\
(-1315)\end{array}$ & $\begin{array}{l}-2.0374 \\
(-1156)\end{array}$ & $\begin{array}{c}-0.3408 \\
(-195)\end{array}$ & $\begin{array}{l}-2.0862 \\
(-1038)\end{array}$ & $\begin{array}{c}-0.5126 \\
(-268)\end{array}$ & $\begin{array}{c}-0.8680 \\
(-4.41)\end{array}$ \\
\hline Car & $\begin{array}{l}0.1748 \\
(2.53)\end{array}$ & $\begin{array}{c}-0.0933 \\
(-1.97)\end{array}$ & $\begin{array}{c}0.3942 \\
(6.45)\end{array}$ & $\begin{array}{l}-- \\
--\end{array}$ & -- & & $\begin{array}{l}-2.2192 \\
(-12.72)\end{array}$ & $\begin{array}{l}-- \\
--\end{array}$ & $\begin{array}{l}-2.0862 \\
(-10.38)\end{array}$ & $\begin{array}{c}-0.2859 \\
(-1.73)\end{array}$ & $\begin{array}{l}-0.7981 \\
(-4.36)\end{array}$ \\
\hline SCU & $\begin{array}{l}-- \\
--\end{array}$ & $\begin{array}{l}-- \\
--\end{array}$ & $\begin{array}{l}-- \\
--\end{array}$ & $\begin{array}{l}-- \\
--\end{array}$ & $\begin{array}{l}-- \\
--\end{array}$ & $\begin{array}{c}-0.8672 \\
(-4.11)\end{array}$ & $\begin{array}{c}-1.1525 \\
(-5.36)\end{array}$ & $\begin{array}{l}-- \\
--\end{array}$ & $\begin{array}{c}-1.2043 \\
(-4.92)\end{array}$ & & $\begin{array}{c}-0.9770 \\
(-3.67)\end{array}$ \\
\hline SUV & $\begin{array}{l}-- \\
--\end{array}$ & $\begin{array}{l}-- \\
--\end{array}$ & $\begin{array}{l}-- \\
--\end{array}$ & $\begin{array}{l}0.3456 \\
(1.68)\end{array}$ & $\begin{array}{l}0.3316 \\
(1.85)\end{array}$ & $\begin{array}{c}-1.6154 \\
(-9.91)\end{array}$ & $\begin{array}{c}-1.6188 \\
(-9.32)\end{array}$ & $\begin{array}{l}-- \\
--\end{array}$ & $\begin{array}{c}-1.8460 \\
(-9.17)\end{array}$ & $\begin{array}{c}-0.2859 \\
(-1.73)\end{array}$ & $\begin{array}{c}-0.6969 \\
(-3.67)\end{array}$ \\
\hline Van & $\begin{array}{l}-- \\
--\end{array}$ & $\begin{array}{l}-- \\
--\end{array}$ & $\begin{array}{l}-- \\
--\end{array}$ & $\begin{array}{l}0.3456 \\
(1.68)\end{array}$ & $\begin{array}{l}0.6416 \\
(2.43)\end{array}$ & $\begin{array}{c}-1.3314 \\
(-6.54)\end{array}$ & $\begin{array}{c}-1.2999 \\
(-5.79)\end{array}$ & $\begin{array}{l}-- \\
--\end{array}$ & $\begin{array}{c}-1.8460 \\
(-9.17)\end{array}$ & $\begin{array}{c}-1.1981 \\
(-3.63)\end{array}$ & $\begin{array}{l}-0.5083 \\
(-2.13)\end{array}$ \\
\hline Pickup & $\begin{array}{l}-- \\
--\end{array}$ & $\begin{array}{l}-- \\
--\end{array}$ & $\begin{array}{c}0.2404 \\
(2.87)\end{array}$ & $\begin{array}{l}-- \\
--\end{array}$ & $\begin{array}{l}-- \\
--\end{array}$ & $\begin{array}{c}-1.6384 \\
(-9.03)\end{array}$ & $\begin{array}{c}-1.6229 \\
(-8.42)\end{array}$ & $\begin{array}{l}-- \\
--\end{array}$ & $\begin{array}{c}-1.8460 \\
(-9.17)\end{array}$ & & $\begin{array}{c}-1.7183 \\
(-8.11)\end{array}$ \\
\hline Gasoline & $\begin{array}{l}-- \\
--\end{array}$ & $\begin{array}{l}-- \\
--\end{array}$ & $\begin{array}{l}-- \\
--\end{array}$ & $\begin{array}{l}-- \\
--\end{array}$ & $\begin{array}{l}-- \\
--\end{array}$ & & & $\begin{array}{c}-0.5164 \\
(-4.32)\end{array}$ & & $\begin{array}{l}-1.1119 \\
(-10.27)\end{array}$ & $\begin{array}{l}-- \\
--\end{array}$ \\
\hline Flex Fuel & $\begin{array}{l}-- \\
--\end{array}$ & $\begin{array}{l}-- \\
--\end{array}$ & -- & $\begin{array}{c}-0.9011 \\
(-1.63)\end{array}$ & $\begin{array}{l}-- \\
--\end{array}$ & $\begin{array}{l}1.9187 \\
(10.17)\end{array}$ & $\begin{array}{l}1.3517 \\
(7.31)\end{array}$ & -- & $\begin{array}{l}2.0346 \\
(14.75)\end{array}$ & $\begin{array}{l}-- \\
--\end{array}$ & $\begin{array}{l}0.8025 \\
(3.48)\end{array}$ \\
\hline Plug-in & $\begin{array}{c}-0.1816 \\
(-2.16)\end{array}$ & $\begin{array}{l}-- \\
--\end{array}$ & $\begin{array}{l}-- \\
--\end{array}$ & $\begin{array}{c}-0.7593 \\
(-2.96)\end{array}$ & $\begin{array}{l}-- \\
--\end{array}$ & $\begin{array}{l}1.8859 \\
(11.73)\end{array}$ & $\begin{array}{l}1.2428 \\
(6.93)\end{array}$ & -- & $\begin{array}{l}2.0346 \\
(14.75)\end{array}$ & $\begin{array}{l}-- \\
--\end{array}$ & $\begin{array}{l}0.6614 \\
(3.69)\end{array}$ \\
\hline CNG & $\begin{array}{c}-0.1816 \\
(-2.16)\end{array}$ & $\begin{array}{l}-- \\
--\end{array}$ & $\begin{array}{l}-- \\
--\end{array}$ & $\begin{array}{c}-1.5793 \\
(-1.67)\end{array}$ & $\begin{array}{l}1.0713 \\
(2.86)\end{array}$ & $\begin{array}{l}0.8919 \\
(3.33)\end{array}$ & $\begin{array}{l}0.9285 \\
(3.56)\end{array}$ & $\begin{array}{l}-- \\
--\end{array}$ & $\begin{array}{l}1.2867 \\
(4.46)\end{array}$ & $\begin{array}{l}-- \\
--\end{array}$ & $\begin{array}{l}-- \\
--\end{array}$ \\
\hline Diesel & -- & $\begin{array}{c}0.1132 \\
(1.52)\end{array}$ & -- & -- & -- & $\begin{array}{l}1.8670 \\
(11.78)\end{array}$ & $\begin{array}{l}1.4401 \\
(8.41)\end{array}$ & -- & $\begin{array}{l}1.5186 \\
(8.05)\end{array}$ & -- & $\begin{array}{c}0.5451 \\
(3.28)\end{array}$ \\
\hline Hybrid & -- & $\begin{array}{l}-- \\
--\end{array}$ & -- & -- & $\begin{array}{c}0.5104 \\
(2.34)\end{array}$ & $\begin{array}{l}1.1027 \\
(8.21)\end{array}$ & $\begin{array}{c}0.8652 \\
(7.16)\end{array}$ & $\begin{array}{c}-0.5752 \\
(-2.61)\end{array}$ & $\begin{array}{l}1.5457 \\
(11.64)\end{array}$ & $\begin{array}{c}-0.5590 \\
(-2.86)\end{array}$ & $\begin{array}{c}0.4686 \\
(3.12)\end{array}$ \\
\hline Fully & $\begin{array}{c}-0.1816 \\
(-2.16)\end{array}$ & $\begin{array}{l}-- \\
--\end{array}$ & $\begin{array}{l}-- \\
--\end{array}$ & $\begin{array}{l}-- \\
--\end{array}$ & -- & $\begin{array}{c}0.5449 \\
(2.61\end{array}$ & $\begin{array}{l}0.6123 \\
(3.19)\end{array}$ & $\begin{array}{l}-- \\
--\end{array}$ & $\begin{array}{l}1.0249 \\
(5.03)\end{array}$ & -- & $\begin{array}{l}-- \\
--\end{array}$ \\
\hline New Car & $\begin{array}{l}-- \\
--\end{array}$ & $\begin{array}{l}-- \\
--\end{array}$ & $\begin{array}{l}-- \\
--\end{array}$ & $\begin{array}{c}0.4248 \\
(4.05)\end{array}$ & $\begin{array}{l}-- \\
--\end{array}$ & $\begin{array}{c}-1.0488 \\
(-7.15)\end{array}$ & $\begin{array}{c}-1.1421 \\
(-7.08)\end{array}$ & $\begin{array}{c}-0.9662 \\
(-5.17)\end{array}$ & $\begin{array}{c}-1.1690 \\
(-5.96)\end{array}$ & $\begin{array}{c}-1.2475 \\
(-6.92)\end{array}$ & $\begin{array}{c}-0.9937 \\
(-5.48)\end{array}$ \\
\hline 1 or 2 years & $\begin{array}{l}-- \\
--\end{array}$ & $\begin{array}{c}0.1556 \\
(3.12)\end{array}$ & $\begin{array}{c}0.2131 \\
(3.32)\end{array}$ & $\begin{array}{l}-- \\
--\end{array}$ & $\begin{array}{l}-- \\
--\end{array}$ & $\begin{array}{c}-0.6136 \\
(-4.43)\end{array}$ & $\begin{array}{c}-0.6546 \\
(-4.09)\end{array}$ & $\begin{array}{c}-0.9662 \\
(-5.17)\end{array}$ & $\begin{array}{c}-0.7563 \\
(-3.81)\end{array}$ & $\begin{array}{c}-0.8028 \\
(-4.16)\end{array}$ & $\begin{array}{c}-0.5891 \\
(-3.24)\end{array}$ \\
\hline 3 to 7 years & $\begin{array}{l}-- \\
--\end{array}$ & $\begin{array}{l}0.2518 \\
(5.87)\end{array}$ & $\begin{array}{l}0.3530 \\
(5.64)\end{array}$ & $\begin{array}{l}-- \\
--\end{array}$ & $\begin{array}{l}-- \\
--\end{array}$ & $\begin{array}{l}-0.103 \\
(-5.92)\end{array}$ & $\begin{array}{c}-0.6546 \\
(-4.09)\end{array}$ & $\begin{array}{c}-0.7738 \\
(-3.62)\end{array}$ & $\begin{array}{c}-0.7563 \\
(-3.81)\end{array}$ & $\begin{array}{c}-0.8028 \\
(-4.16)\end{array}$ & $\begin{array}{c}-0.5891 \\
(-3.24)\end{array}$ \\
\hline 8 to 12 & $\begin{array}{c}0.4773 \\
(4.42)\end{array}$ & $\begin{array}{c}0.2673 \\
(4.35)\end{array}$ & $\begin{array}{c}0.3782 \\
(4.26)\end{array}$ & $\begin{array}{l}-- \\
--\end{array}$ & $\begin{array}{l}-- \\
--\end{array}$ & $\begin{array}{l}-- \\
--\end{array}$ & $\begin{array}{l}-- \\
--\end{array}$ & $\begin{array}{l}-- \\
--\end{array}$ & $\begin{array}{l}-- \\
--\end{array}$ & $\begin{array}{l}-- \\
--\end{array}$ & $\begin{array}{l}-- \\
--\end{array}$ \\
\hline$>12$ years & $\begin{array}{c}0.4773 \\
(4.42)\end{array}$ & $\begin{array}{c}0.2673 \\
(4.35)\end{array}$ & $\begin{array}{c}0.3782 \\
(4.26)\end{array}$ & $\begin{array}{l}-- \\
--\end{array}$ & $\begin{array}{l}-- \\
--\end{array}$ & $\begin{array}{l}-- \\
--\end{array}$ & $\begin{array}{l}-- \\
--\end{array}$ & $\begin{array}{l}-- \\
--\end{array}$ & $\begin{array}{l}-- \\
--\end{array}$ & $\begin{array}{l}-- \\
--\end{array}$ & $\begin{array}{l}-- \\
--\end{array}$ \\
\hline
\end{tabular}


TABLE 2a Estimates of the Vehicle Type Choice Component of Vehicle Selection Module (Continued)

\begin{tabular}{|c|c|c|c|c|c|c|c|}
\hline \multirow{2}{*}{ Variables $\rightarrow$} & \multicolumn{7}{|c|}{ Replaced Vehicle Characteristics } \\
\hline & Compact Car & Car & SCU & SUV & Van & Pickup & Gasoline \\
\hline No vehicle & $\begin{array}{l}-- \\
--\end{array}$ & $\begin{array}{l}-- \\
--\end{array}$ & $\begin{array}{l}- \\
--\end{array}$ & $\begin{array}{l}-- \\
--\end{array}$ & -- & -- & -- \\
\hline CC & $\begin{array}{l}0.5665 \\
(2.17)\end{array}$ & $\begin{array}{c}-1.5864 \\
(-8.82)\end{array}$ & $\begin{array}{c}-0.9648 \\
(-2.60)\end{array}$ & $\begin{array}{c}-1.3750 \\
(-4.44)\end{array}$ & $\begin{array}{l}-- \\
--\end{array}$ & $\begin{array}{c}-2.1573 \\
(-6.32)\end{array}$ & $\begin{array}{l}1.5717 \\
(6.06)\end{array}$ \\
\hline Car & $\begin{array}{l}-- \\
--\end{array}$ & $\begin{array}{l}1.9106 \\
(12.55)\end{array}$ & & $\begin{array}{c}0.9306 \\
(4.41)\end{array}$ & $\begin{array}{l}1.1680 \\
(3.86)\end{array}$ & $\begin{array}{c}-0.7985 \\
(-2.90)\end{array}$ & $\begin{array}{l}-- \\
--\end{array}$ \\
\hline SCU & $\begin{array}{l}-- \\
--\end{array}$ & $\begin{array}{l}-- \\
--\end{array}$ & $\begin{array}{c}2.5700 \\
(9.41)\end{array}$ & $\begin{array}{l}-- \\
--\end{array}$ & $\begin{array}{l}-- \\
--\end{array}$ & $\begin{array}{l}-- \\
--\end{array}$ & $\begin{array}{l}0.5343 \\
(3.20)\end{array}$ \\
\hline SUV & -- & -- & -- & 2.6388 & 1.6229 & -- & -- \\
\hline & -- & -- & -- & $(12.72)$ & $(5.97)$ & -- & -- \\
\hline Van & -- & -- & -- & & 4.7040 & -- & -- \\
\hline Pickup & $\begin{array}{l}-- \\
--\end{array}$ & $\begin{array}{c}-0.4319 \\
(-1.64)\end{array}$ & -- & $\begin{array}{c}1.3940 \\
(5.06)\end{array}$ & $\begin{array}{c}(10.04) \\
-- \\
--\end{array}$ & $\begin{array}{l}4.3382 \\
(15.92)\end{array}$ & $\begin{array}{c}-0.8290 \\
(-4.47)\end{array}$ \\
\hline Gasoline & $\begin{array}{r}-0.4069 \\
(-3.46)\end{array}$ & $\begin{array}{l}-- \\
--\end{array}$ & $\begin{array}{c}-0.6777 \\
(-3.11)\end{array}$ & $\begin{array}{l}-- \\
--\end{array}$ & $\begin{array}{l}-- \\
--\end{array}$ & $\begin{array}{c}-1.14 \\
(-5.24)\end{array}$ & $\begin{array}{l}-- \\
--\end{array}$ \\
\hline Flex Fuel & $\begin{array}{l}-- \\
--\end{array}$ & $\begin{array}{l}-- \\
--\end{array}$ & -- & $\begin{array}{l}-- \\
--\end{array}$ & $\begin{array}{l}-- \\
--\end{array}$ & $\begin{array}{c}-0.8779 \\
(-2.69)\end{array}$ & $\begin{array}{c}0.7836 \\
(3.61)\end{array}$ \\
\hline Plug-in Hybrid & $\begin{array}{l}-- \\
--\end{array}$ & $\begin{array}{c}0.5869 \\
(2.79)\end{array}$ & $\begin{array}{l}-- \\
--\end{array}$ & -- & $\begin{array}{c}0.8307 \\
(2.87)\end{array}$ & $\begin{array}{c}-0.9392 \\
(-2.90)\end{array}$ & $\begin{array}{l}0.8037 \\
(3.77)\end{array}$ \\
\hline CNG & $\begin{array}{l}-- \\
--\end{array}$ & $\begin{array}{l}-- \\
--\end{array}$ & $\begin{array}{l}-- \\
--\end{array}$ & $\begin{array}{l}-- \\
--\end{array}$ & $\begin{array}{l}-- \\
--\end{array}$ & $\begin{array}{l}-- \\
--\end{array}$ & $\begin{array}{l}-- \\
--\end{array}$ \\
\hline Diesel & $\begin{array}{l}-- \\
--\end{array}$ & $\begin{array}{c}0.7886 \\
(3.63)\end{array}$ & $\begin{array}{l}-- \\
--\end{array}$ & $\begin{array}{c}1.0441 \\
(4.27)\end{array}$ & $\begin{array}{l}-- \\
--\end{array}$ & $\begin{array}{c}0.7583 \\
(2.54)\end{array}$ & $\begin{array}{c}-0.6766 \\
(-3.82)\end{array}$ \\
\hline Hybrid Electric & $\begin{array}{l}-- \\
--\end{array}$ & $\begin{array}{l}-- \\
--\end{array}$ & $\begin{array}{l}-- \\
--\end{array}$ & $\begin{array}{l}-- \\
--\end{array}$ & $\begin{array}{l}-- \\
--\end{array}$ & $\begin{array}{c}-1.6336 \\
(-5.89)\end{array}$ & $\begin{array}{l}1.5442 \\
(12.07)\end{array}$ \\
\hline Fully Electric & $\begin{array}{l}-- \\
-- \\
\end{array}$ & $\begin{array}{l}-- \\
-- \\
\end{array}$ & -- & $\begin{array}{l}-- \\
-- \\
\end{array}$ & $\begin{array}{l}-- \\
-- \\
\end{array}$ & $\begin{array}{l}-- \\
-- \\
\end{array}$ & $\begin{array}{c}-0.5583 \\
(-2.32) \\
\end{array}$ \\
\hline & $\begin{array}{c}-0.1958 \\
(-1.61)\end{array}$ & $\begin{array}{l}- \\
--\end{array}$ & $\begin{array}{l}- \\
--\end{array}$ & $\begin{array}{l}1.7986 \\
(2.84)\end{array}$ & $\begin{array}{l}- \\
--\end{array}$ & $\begin{array}{l}0.4506 \\
(2.82)\end{array}$ & $\begin{array}{l}3.3215 \\
(8.10)\end{array}$ \\
\hline 1 or 2 years & -- & -- & $\begin{array}{l}-- \\
--\end{array}$ & $\begin{array}{c}1.7986 \\
(2.84)\end{array}$ & $\begin{array}{l}-- \\
--\end{array}$ & -- & $\begin{array}{l}3.3215 \\
(8.10)\end{array}$ \\
\hline 3 to 7 years & $\begin{array}{l}-- \\
--\end{array}$ & $\begin{array}{l}-- \\
--\end{array}$ & $\begin{array}{l}-- \\
--\end{array}$ & $\begin{array}{c}1.7986 \\
(2.84)\end{array}$ & $\begin{array}{l}-- \\
--\end{array}$ & $\begin{array}{l}-- \\
--\end{array}$ & $\begin{array}{l}3.3215 \\
(8.10)\end{array}$ \\
\hline 8 to 12 years & $\begin{array}{l}-- \\
--\end{array}$ & $\begin{array}{l}-- \\
--\end{array}$ & $\begin{array}{l}-- \\
--\end{array}$ & $\begin{array}{l}-- \\
--\end{array}$ & $\begin{array}{l}-- \\
--\end{array}$ & $\begin{array}{l}-- \\
--\end{array}$ & $\begin{array}{l}2.0138 \\
(4.66)\end{array}$ \\
\hline$>12$ years & $\begin{array}{l}-- \\
--\end{array}$ & $\begin{array}{l}-- \\
--\end{array}$ & $\begin{array}{l}-- \\
--\end{array}$ & $\begin{array}{l}-- \\
--\end{array}$ & $\begin{array}{l}-- \\
--\end{array}$ & $\begin{array}{l}-- \\
--\end{array}$ & $\begin{array}{l}-- \\
--\end{array}$ \\
\hline
\end{tabular}


TABLE 2b Estimates of the Vehicle Usage Component of Vehicle Selection Module

\begin{tabular}{||l|c|c||}
\hline \multicolumn{1}{||c|}{ Variable } & Parameter & t-stat \\
\hline Constant & 8.4682 & 128.77 \\
HH Income & & \\
$\quad$ Above \$80K & 0.0401 & 2.25 \\
Presence of children & & \\
Under 4 years & 0.0398 & 1.58 \\
Location of HH & & \\
Sub-urban & 0.1074 & 6.61 \\
Presence of senior adults (age>65 years) & -0.1281 & -5.97 \\
Number of vehicles & & \\
Two & -0.0662 & -2.71 \\
Three & -0.1667 & -5.56 \\
Four & -0.2524 & -6.21 \\
Number of workers & 0.0763 & 6.83 \\
Mean distance to work /10 (miles) & 0.091 & 12.67 \\
Vehicle Characteristics & & \\
Car & 0.0446 & 1.85 \\
Small cross utility vehicle & -0.1329 & -3.01 \\
SUV or Van & 0.0767 & 2.93 \\
8 to 12 years old & -0.4298 & -8.09 \\
More than 12 years old & -0.7189 & -12.87 \\
Standard error of the estimate & 0.7476 & 42.42 \\
\hline Scale Parameter $(\lambda)$ & 0.5538 & $23.91 *$ \\
Copula Dependency Parameter $(\theta)$ & -3.4097 & -9.38 \\
\hline \hline
\end{tabular}

* t-statistic computed against a value of 1 
TABLE 3 Disaggregate Measures of Fit for the Validation Sample

\begin{tabular}{||l|c|c|c|c||}
\hline Sample details & $\begin{array}{c}\text { Number of } \\
\text { households }\end{array}$ & $\begin{array}{c}\text { Independent } \\
\text { model } \\
\text { predictive } \\
\text { likelihood }\end{array}$ & $\begin{array}{c}\text { Copula } \\
\text { based joint } \\
\text { model } \\
\text { predictive } \\
\text { likelihood }\end{array}$ & $\begin{array}{c}\text { Predictive } \\
\text { likelihood ratio } \\
\text { test } \\
\left(\chi_{1,0.05}^{2}=3.84\right)\end{array}$ \\
\hline $\begin{array}{l}\text { Full validation sample } \\
\text { Number of vehicles }\end{array}$ & 500 & -14189.96 & -14084.80 & 208.29 \\
Zero & 6 & -157.011 & -156.08 & 1.86 \\
One & 152 & -3030.74 & -3013.22 & 35.04 \\
Two & 225 & -6337.90 & -6298.90 & 77.99 \\
Three & 89 & -3292.88 & -3256.84 & 72.09 \\
Four or more & 28 & -1370.43 & -1359.78 & 21.30 \\
Number of workers & & & & \\
Zero & 90 & -2123.99 & -2116.89 & 14.20 \\
One & 171 & -4513.83 & -4484.28 & 59.08 \\
Two & 196 & -5857.35 & -5806.80 & 101.09 \\
Three & 37 & -1380.86 & -1365.08 & 31.57 \\
Four or more & 6 & -312.93 & -311.77 & 2.32 \\
Highest Educational Attainment & & & & \\
High school & 43 & -1117.53 & -1108.82 & 20.68 \\
College (With/without degree) & 271 & -7768.68 & -7726.33 & 100.78 \\
Post Graduate & 186 & -5302.75 & -5271.41 & 86.83 \\
Presence of children & & & & \\
0-4 years & 57 & -1679.78 & -1661.28 & 37.00 \\
5-11 years & 74 & -2197.82 & -2179.51 & 36.63 \\
12-15 years & 58 & -1917.09 & -1891.06 & 52.06 \\
Presence of senior adults & & & \\
$\quad$ Age $\geq 65$ years) & 113 & -2902.10 & -2890.35 & 23.51 \\
Region & & & & \\
Urban & 241 & -6704.93 & -6652.75 & 104.36 \\
Sub-urban & 235 & -6785.54 & -6740.34 & 90.40 \\
Rural & 24 & -698.49 & -691.72 & 13.53 \\
\hline
\end{tabular}


TABLE 4a Replacement Decision of Evolution Module: Binary Logit Model

\begin{tabular}{||l|c|c||}
\hline \multicolumn{1}{|c|}{ Variable } & Parameter & t statistic \\
\hline Constant & -1.9667 & -8.84 \\
Race of household (other race is base) & & \\
Caucasian & 0.1108 & 1.59 \\
Hispanic & 0.7353 & 1.43 \\
Household Income (Base is below \$60,000) & & \\
Between \$60,000 and \$100,000 & 0.1065 & 1.26 \\
Above \$120,000 & 0.1689 & 1.76 \\
Presence of children & & \\
5 to 11 years & -0.1736 & -1.79 \\
12 to 15 years & 0.4677 & 3.20 \\
Characteristics of vehicle getting replaced & & \\
Small cross utility vehicle & -0.4269 & -2.21 \\
SUV & -0.2567 & -2.57 \\
SUV*Large Household & -0.4565 & -2.23 \\
Van & -0.2168 & -1.55 \\
Pickup & -0.1997 & -1.92 \\
1-3 years old & 0.1432 & 1.40 \\
3-7 years old & 0.3125 & 3.23 \\
8-12 years old & 0.6889 & 4.18 \\
More than 12 years old & 0.548 & 3.01 \\
Gasoline Fueled & 0.3529 & 1.71 \\
Number of years since acquired (Base is 5 or more years) & -1.8907 & -4.81 \\
1 year & -1.1948 & -5.96 \\
2 years & 0.8159 & -8.02 \\
3 or 4 years & 0.2910 & 14.23 \\
Number of years since a vehicle has been replaced & & 3.31 \\
Number of years since a vehicle has been added & & \\
\hline Log Likelihood & & \\
Log Likelihood at constants & & \\
\hline \hline
\end{tabular}


TABLE 4b Addition Decision of Evolution Module: Binary Logit Model

\begin{tabular}{|c|c|c|}
\hline Variable & Parameter & t statistic \\
\hline Constant & -3.7901 & -5.60 \\
\hline \multicolumn{3}{|l|}{ Race of the household (other race is base) } \\
\hline Caucasian & -0.4064 & -1.77 \\
\hline Hispanic & -9.576 & -9.49 \\
\hline Number of adults & 0.8129 & 5.14 \\
\hline Large Household ( size >=5) & 0.7117 & 2.16 \\
\hline \multicolumn{3}{|l|}{ Household Income (Base is above $\$ 20,000$ ) } \\
\hline Between $\$ 20,000$ & 1.4209 & 2.96 \\
\hline Presence of children 12 to 15 years & 1.2988 & 4.48 \\
\hline Presence of senior adults (age > 65 years) & -1.8651 & -3.36 \\
\hline \multicolumn{3}{|l|}{ Region (Base is urban and sub-urban) } \\
\hline Rural & 0.9864 & 2.07 \\
\hline \multicolumn{3}{|l|}{ Household Vehicle Fleet Characteristics } \\
\hline Number of compact cars & -0.7671 & -3.16 \\
\hline Number of cars & -0.4622 & -2.01 \\
\hline Number of SUVs & -0.2942 & -1.57 \\
\hline Number of Pickup trucks & -0.5665 & -2.28 \\
\hline \multicolumn{3}{|c|}{ Number of years since a vehicle has been replaced (Base is four or more years) } \\
\hline Same year & -1.0295 & -1.62 \\
\hline One to three years & -0.8189 & -1.28 \\
\hline Log Likelihood & \multicolumn{2}{|c|}{-428.88} \\
\hline Log Likelihood at constants & \multicolumn{2}{|c|}{-506.45} \\
\hline
\end{tabular}

